\title{
Article \\ Global Transcriptional Response of Aspergillus niger to Blocked Active Citrate Export through Deletion of the Exporter Gene
}

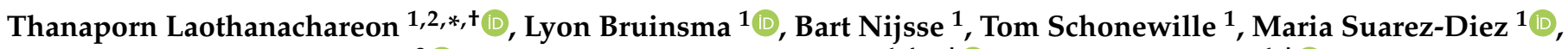 \\ Juan Antonio Tamayo-Ramos ${ }^{3}$ (), Vitor A. P. Martins dos Santos ${ }^{1,4, *, \neq(1)}$ and Peter J. Schaap ${ }^{1, \ddagger(1)}$ \\ 1 Laboratory of Systems and Synthetic Biology, Department of Agrotechnology and Food Sciences, \\ Wageningen University \& Research, 6708 WE Wageningen, The Netherlands; lyon.bruinsma@wur.nl (L.B.); \\ bart.nijsse@wur.nl (B.N.); tom.schonewille@wur.nl (T.S.); maria.suarezdiez@wur.nl (M.S.-D.); \\ peter.schaap@wur.nl (P.J.S.) \\ 2 Enzyme Technology Laboratory, Biorefinery and Bioproduct Research Group, National Center for Genetic \\ Engineering and Biotechnology, 113 Thailand Science Park, Khlong Luang, Pathumthani 12120, Thailand \\ 3 International Research Center in Critical Raw Materials-ICCRAM, University of Burgos, 09001 Burgos, Spain; \\ jatramos@ubu.es \\ 4 LifeGlimmer GmbH, 12163 Berlin, Germany \\ * Correspondence: thanaporn.lao@biotec.or.th (T.L.); vitor.martinsdossantos@wur.nl (V.A.P.M.d.S.) \\ + Current address: Enzyme Technology Laboratory, Biorefinery and Bioproduct Technology Research Group, \\ National Center for Genetic Engineering and Biotechnology, 113 Thailand Science Park, Khlong Luang, \\ Patumthani 12120, Thailand. \\ $\ddagger$ These authors contributed equally as senior authors.
}

Citation: Laothanachareon, T.; Bruinsma, L.; Nijsse, B.; Schonewille, T.; Suarez-Diez, M.; Tamayo-Ramos, J.A.;

Martins dos Santos, V.A.P.; Schaap, P.J. Global Transcriptional Response of Aspergillus niger to Blocked Active Citrate Export through Deletion of the Exporter Gene. J. Fungi 2021, 7, 409. https://doi.org/10.3390/jof7060409

Academic Editors: Craig Faulds and Putarak Chomnunti

Received: 27 April 2021

Accepted: 21 May 2021

Published: 23 May 2021

Publisher's Note: MDPI stays neutral with regard to jurisdictional claims in published maps and institutional affiliations.

Copyright: (c) 2021 by the authors. Licensee MDPI, Basel, Switzerland. This article is an open access article distributed under the terms and conditions of the Creative Commons Attribution (CC BY) license (https:// creativecommons.org/licenses/by/ $4.0 /)$.
Abstract: Aspergillus niger is the major industrial citrate producer worldwide. Export as well as uptake of citric acid are believed to occur by active, proton-dependent, symport systems. Both are major bottlenecks for industrial citrate production. Therefore, we assessed the consequences of deleting the cit $T$ gene encoding the $A$. niger citrate exporter, effectively blocking active citrate export. We followed the consumption of glucose and citrate as carbon sources, monitored the secretion of organic acids and carried out a thorough transcriptome pathway enrichment analysis. Under controlled cultivation conditions that normally promote citrate secretion, the knock-out strain secreted negligible amounts of citrate. Blocking active citrate export in this way led to a reduced glucose uptake and a reduced expression of high-affinity glucose transporter genes, $m s t G$ and $m s t H$. The glyoxylate shunt was strongly activated and an increased expression of the OAH gene was observed, resulting in a more than two-fold higher concentration of oxalate in the medium. Deletion of $\operatorname{cit} T$ did not affect citrate uptake suggesting that citrate export and citrate uptake are uncoupled from the system.

Keywords: Aspergillus niger; citrate exporter; citT gene; cexA gene; transcriptome; citric acid; oxalic acid

\section{Introduction}

Aspergillus niger is a versatile, industrially competitive fungal chassis due to its excellent performance in the hydrolysis of carbohydrates, and its naturally high secretion capacity of proteins and organic acids. These characteristics make $A$. niger a proficient cell factory for the production of industrial enzymes such as glucoamylases, phytase and lignocellulosic degrading enzymes, and organic acids, especially citric acid [1-3]. Currently, up to $99 \%$ of the global production of citric acid involves a microbial process, $80 \%$ of which use $A$. niger as cell factory [4,5]. In the industrial demands, the high yield and productivity have become a primary requirement. To achieve high yields, media composition and environmental factors such as the available carbon and nitrogen sources, phosphate concentration, $\mathrm{pH}$ of the medium, oxygen supply, and the influence of trace elements have been optimized. 
The environmental $\mathrm{pH}$ dictates the organic acid profile of wild-type $A$. niger. In synthetic media with glucose as carbon source, substantial amounts of oxalic acid are produced as long as the $\mathrm{pH}$ of the culture is 3 or above [6]. At around $\mathrm{pH} 3$, A. niger starts producing citric acid while the optimal $\mathrm{pH}$ for the accumulation of the tricarboxylic acid is around pH 2 [7-9]. The influence of the dissolved oxygen tension (DOT) in the production of citrate has been described too, and is significantly higher than that needed for growth [10]. Moreover, trace elements have a crucial impact on citric acid accumulation [11]. Copper, iron, and/or zinc can enhance the maximum yield of citric acid, whereas manganese strongly represses citric acid formation [12].

Owing to the capacity of $A$. niger to produce a variety of valuable organic acids, many attempts have been made towards improving $A$. niger strains to reduce undesired by-products, optimize production yields, and lower manufacturing costs. Nevertheless, the role of membrane transporters, frequently considered to be industrial bottlenecks, are still only partially understood $[7,13]$. The $A$. niger transportome that governs cellular influx and efflux of nutrients, ions, and metabolites is extensive and complex. In silico analysis of the theoretical $A$. niger proteome with precomputed profile hidden Markov models obtained from the Pfam database [14], showed that the A. niger ATCC1015 genome [15] codes for more than 500 transporter proteins, of which some 250 are predicted to be major facilitator super family proteins with a conserved domain architecture related to sugar transport [16]. Very similar results were obtained for the A. niger CBS 513.88 genome [17] and the laboratory strain N402 [18] used in this study.

Recently, there have been reports on the discovery of a citrate transporter gene of $A$. niger (cit $T$, alternative name cex $A$ ), responsible for active export of citric acid over the plasma membrane [19-21]. The heterologous expression of the cit $T$ gene resulted in citric acid secretion in yeast $[20,21]$, whereas its overexpression in $A$. niger itself strongly boosted the secretion of citric acid, yielding for 5-times higher than the parental strain [21]. These results are very promising for the citric acid manufacturing industries. Creating a new strain by overexpressing the cit $T$ gene becomes an excellent option to powerfully improve productivity. Furthermore, the deletion of this gene opens new avenues for rerouting pathways in $A$. niger to produce other organic acids, since citric acid cannot be secreted outside the fungal cell. Hence, here we further elucidate the role of this transporter under industrially relevant conditions, by setting to assess the consequences of deleting the cit $T$. To this end, we followed the consumption of glucose and citrate as carbon sources at low $\mathrm{pH}$ and under controlled cultivation conditions. To study uptake, citrate was used as a sole carbon source, while glucose was used to promote citrate secretion. Fermentation profiles were followed by HPLC to monitor consumption of the selected carbon sources and the secretion of organic acids. Transcriptome and pathway enrichment analysis were performed to explore the underlying gene networks by comparing the responses of the wild-type and the knock-out strain under the different conditions tested. We show that the cit $T$ gene is responsible for active $A$. niger citrate export, but not for citrate uptake. Blocking active citrate export under citrate producing conditions reduces the uptake of glucose, induces the secretion of oxalic acid and activates the glyoxylate shunt. Growth on citrate in addition leads to oxalic acid formation.

\section{Materials and Methods}

\subsection{Strains Media, Growth, and Fermentation Conditions}

Strains: A. niger N402 (cspA1) [22] and MA169.4 (cspA1: pyrG378, kusA::DR-amdS$D R$ ) [23] are used as control and recipient strain. A. niger strains were maintained on complete medium $(\mathrm{CM})$ at $30{ }^{\circ} \mathrm{C}$. The MA169.4 strain requires $0.82 \mathrm{mM}$ and $10 \mathrm{mM}$ uridine for solid or liquid medium, respectively.

Standard media: Complete medium (CM): $1 \mathrm{~g} / \mathrm{L}$ casamino acid, $5 \mathrm{~g} / \mathrm{L}$ yeast extract, $1 \%$ glucose, $20 \mathrm{~mL} / \mathrm{L}$ ASPA + N (stock solution $50 \times: \mathrm{NaNO}_{3} 297.5 \mathrm{~g} / \mathrm{L}, \mathrm{KCl} 26.1 \mathrm{~g} / \mathrm{L}$ and $\mathrm{KH}_{2} \mathrm{PO}_{4} 74.8 \mathrm{~g} / \mathrm{L}$ at $\left.\mathrm{pH} 5.5\right), 1 \mathrm{~mL} / \mathrm{L}$ Vishniac solution [24], $1 \mathrm{mM} \mathrm{MgSO}_{4}$, and adjusted to pH 5.5 [25]. 
Fermentation and screening media: Screening medium (SM): $1.2 \mathrm{~g} / \mathrm{L} \mathrm{NaNO}_{3}, 0.5 \mathrm{~g} / \mathrm{L}$ $\mathrm{KH}_{2} \mathrm{PO}_{4}, 0.2 \mathrm{~g} / \mathrm{L} \mathrm{MgSO}_{4} \cdot 7 \mathrm{H}_{2} \mathrm{O}, 40 \mu \mathrm{L} / \mathrm{L}$ Vishniac, adjusted to $\mathrm{pH} 3.5$ and supplemented with carbon source. Mycerium preparation medium (CM-SLZ): $1 \mathrm{~g} / \mathrm{L}$ casamino acid, $5 \mathrm{~g} / \mathrm{L}$ yeast extract, $3 \mathrm{~g} / \mathrm{L}\left(\mathrm{NH}_{4}\right)_{2} \mathrm{SO}_{4}, 1 \mathrm{~g} / \mathrm{L} \mathrm{K}_{2} \mathrm{HPO}_{4}, 1 \mathrm{~g} / \mathrm{L} \mathrm{KH}_{2} \mathrm{PO}_{4}, 0.5 \mathrm{~g} / \mathrm{L} \mathrm{MgSO} \cdot 7 \mathrm{H}_{2} \mathrm{O}$, $0.014 \mathrm{mg} / \mathrm{L} \mathrm{MnSO}_{4} \cdot 5 \mathrm{H}_{2} \mathrm{O}, 0.01 \mathrm{mg} / \mathrm{L} \mathrm{FeCl}_{2} \cdot 6 \mathrm{H}_{2} \mathrm{O}, 0.075 \mu \mathrm{g} / \mathrm{L} \mathrm{ZnCl}_{2}, 1 \mathrm{~mL} / \mathrm{L}$ Vishniac solution, adjusted to $\mathrm{pH} 5.5$, and supplemented with $10 \mathrm{~g} / \mathrm{L}$ glucose. Citric acid production medium (SLZ): $3 \mathrm{~g} / \mathrm{L}\left(\mathrm{NH}_{4}\right)_{2} \mathrm{SO}_{4}, 1 \mathrm{~g} / \mathrm{L} \mathrm{K}_{2} \mathrm{HPO}_{4}, 1 \mathrm{~g} / \mathrm{L} \mathrm{KH}_{2} \mathrm{PO}_{4}, 0.5 \mathrm{~g} / \mathrm{L} \mathrm{MgSO} 47 \mathrm{H}_{2} \mathrm{O}$, $0.014 \mathrm{mg} / \mathrm{L} \mathrm{MnSO}_{4} \cdot 5 \mathrm{H}_{2} \mathrm{O}, 0.01 \mathrm{mg} / \mathrm{L} \mathrm{FeCl}_{2} \cdot 6 \mathrm{H}_{2} \mathrm{O}, 0.075 \mu \mathrm{g} / \mathrm{L} \mathrm{ZnCl}_{2}$, adjusted to $\mathrm{pH} 2.5$, and supplemented with $120 \mathrm{~g} / \mathrm{L}$ glucose [26].

Screening of the $\Delta c i t T$ knock-out strains was performed by shake flask experiments. Mycelium was pregrown with $1 \times 10^{6}$ spores $/ \mathrm{mL}$ in $\mathrm{CM}$ at $30^{\circ} \mathrm{C}, 200 \mathrm{rpm}$, for $18 \mathrm{~h}$. The mycelium was harvested, washed with sterile water and transferred to SM supplemented with $10 \mathrm{~g} / \mathrm{L}$ of glucose as carbon sources. The culture was incubated at $30^{\circ} \mathrm{C}, 200 \mathrm{rpm}$ and the supernatants were taken every $24 \mathrm{~h}$ for analysis of the organic acid content by HPLC.

Controlled fermentations were performed in 1-L fermenters with a working volume of $0.75 \mathrm{~L}$. The temperature was fixed at $30{ }^{\circ} \mathrm{C} .30 \%(v / v)$ polypropylene glycol (ppg) was added as an anti-foaming agent $(500 \mu \mathrm{L} / \mathrm{L}$ at final concentration). The aeration was supplied by sterile compressed air continuously blown through a sparger at a rate of $0.6 \mathrm{slpm}$ and the stirring speed was adjusted at $1000 \mathrm{rpm}$.

To study citrate secretion, $1 \times 10^{6}$ spores $/ \mathrm{mL}$ spores were inoculated in $200 \mathrm{~mL} \mathrm{CM}$ SLZ and incubated at $30{ }^{\circ} \mathrm{C}, 200 \mathrm{rpm}$, for $18 \mathrm{~h}$. Mycelium was reaped and then rinsed with equal amounts of water and $10 \mathrm{~g}$ wet weight ( $\sim 92 \mathrm{~g}$ cell dry weight, CDW) of mycelium was transferred to $750 \mathrm{~mL}$ of SLZ medium adjusted to $\mathrm{pH} 2.5$ with $120 \mathrm{~g} / \mathrm{L}$ glucose as carbon source. Methanol $(2 \%(v / v))$ was added as a promotive element for citrate secretion [27]. The $\mathrm{pH}$ was controlled and maintained at $\mathrm{pH} 2.5$ by addition of $5 \mathrm{M} \mathrm{NaOH}$.

To study citrate uptake pre-cultures were prepared in CM and then transferred to $750 \mathrm{~mL}$ of SM, supplemented with $10.5 \mathrm{~g} / \mathrm{L}$ citric acid monohydrate as carbon source. The $\mathrm{pH}$ was not controlled.

Mycelium was collected every $24 \mathrm{~h}$, quickly washed within $30 \mathrm{sec}$ with demineralized water, and then dried with a single-use towel, snap-frozen with liquid nitrogen and stored at $-80{ }^{\circ} \mathrm{C}$ until further processing. Glucose and citrate consumption, and organic acid production were followed by high-performance liquid chromatography analysis (HPLC) as described previously [28].

\subsection{Construction and Initial Screening of $\Delta$ citT Knock-Out Strains for Citrate Secretion}

A. niger citrate exporter knock-out strains were constructed using the split-marker approach [29]. The citT gene was deleted from the MA169.4 genome (isogenic with N402), which is defective in the Non-Homologous End-Joining (NHEJ) pathway through a transiently silenced kusA gene [30]. A protoplast-mediated transformation of A. niger MA169.4 was performed by adapting the protocol of Arentshorst et al. [25] as described in Laothanachareon et al. [18]. Lysing enzymes from Trichoderma harzianum (Sigma) were used for protoplast formation (400 mg enzymes per $\mathrm{g}$ mycelium). The experimental steps representing the construction of the knock-out strains can be found in Supplementary Figure S1 online. Correct deletion of the gene was confirmed with PCR and complete genome sequencing of a selected knock-out strain. PCR primers used are in Supplementary Table S1 online.

For initial screening of knock-out transformant strains, shake flasks were used. The control strain $\mathrm{N} 402$ and the three $\Delta$ cit $T$ candidates were pre-cultured in $\mathrm{CM}$ containing $1 \times 10^{6}$ spores $/ \mathrm{mL}$ at $30{ }^{\circ} \mathrm{C}$ and $200 \mathrm{rpm}$. After $18 \mathrm{~h}$, mycelium was harvested and then rinsed with equal amounts of sterile water (approx. $200 \mathrm{~mL}$ ). Mycelium (5 g wet weight) was transferred to $200 \mathrm{~mL} \mathrm{SM}$ medium supplemented with $18 \mathrm{~g} / \mathrm{L}$ glucose or $10.5 \mathrm{~g} / \mathrm{L}$ citrate as carbon sources, and then incubated at $30{ }^{\circ} \mathrm{C}, 200 \mathrm{rpm}$. Supernatant was collected every $24 \mathrm{~h}$ to determine the amount of carbon source consumption and organic acid production by HPLC. After screening, one $\Delta c i t T$ strain was chosen, completely sequenced, 
and used in fermentation for determining $\Delta c i t T$ acid profiles and preparing samples for RNA sequencing.

\subsection{Genome Sequencing of the citT Mutant, Comparative Genomics and Bioinformatics}

Whole genome sequencing of the selected strain $\Delta c i t T$ strain was performed by Novogene using Illumina HiSeq (300 bp inserts library with 150 bp paired-end sequencing). Two strategies were used to confirm the integrity of the selected strain. Read mapping against A. niger N402 genome using STAR v2.5.0c [31] to establish that there was a complete and clean deletion of the citT gene and assembly the HiSeq reads into contigs using a de novo IDBA_UD [32]-based assembly pipeline showing that the citT gene at the genomic position was replaced by a single copy of the $A$. oryzae pyrG gene.

Comparative genomics of strain N402 and citrate hyper-producing strain H915-1 was done with SibeSibelia [33] and a direct read mapping of N402 Illumina HiSeq reads [18] against the H915-1 genome.

The raw sequencing data (DNA and RNA) have been submitted to the European Nucleotide Archive (ENA) and can be found under the accession number ERS3465414.

\subsection{Transcriptome and Pathway Enrichment Analysis}

Total RNA of A. niger was isolated as described in Sloothaak et al. [34]. The quality and quantity of the RNA were assessed by Qsep $100^{\mathrm{TM}}$ analyzer (BiOptic) and samples with a quality of 6 or more were selected for RNA sequencing analysis. Total RNA was sent to Novogene Bioinformatics Technology Co. Ltd., (Beijing, China) for whole transcriptome shotgun sequencing.

RNA seq data processing: Read mapping against $A$. niger $\mathrm{N} 402$ genome was performed using STAR v2.5.0c [31]. Gene coverage calculations were performed using BEDTools v2.17.0 [35], and subsequently normalized for the respective library sizes. Differential expression analysis was performed using the R package edgeR [36]. RNAseq normalization and differential expression was performed simultaneously for each comparison. Genes with a count per million $(\mathrm{CPM}) \geq 1$ in at least two samples were considered to be expressed and kept for further analysis. Trimmed mean of $\mathrm{M}$-values normalization was performed as implemented in the R package edgeR. $p$-values were corrected for multiple testing using the Benjamini-Hochberg procedure. The terms "differentially expressed" and "overexpressed" refer to differences in read counts per CDS, and denote a fold change $\geq 1.5$ (FDR $\leq 0.05$ ).

Enrichment analyses were performed using the hypergeometric function to model the probability density using the "phyper" function from the R package stats [37]. Two types of analysis were performed: KEGG pathway and GO enrichment [38,39]. For the hypergeometric test we considered the universe size, $\mathrm{N}$, to be the total number of EC numbers in all pathways in the genome, $\mathrm{m}$ is the number of successes in this universe and is defined as the number of EC numbers in the corresponding pathway in the genome, $\mathrm{k}$ and $\mathrm{x}$ are the sample size and the number of successes in the sample (or considered gene subset) respectively. Enrichments with a $p$-value lower than 0.05 were considered significant. GO enrichment analyses were performed with Bingo [40].

\section{Results}

\subsection{Genome Comparison between Strain N402 and the Citrate-Hyperproducing Strain H915-1}

Historically, A. niger strains have been characterized and individually labeled as efficient producers of a specific organic acid. For instance, strain ATCC 1015 is considered to be a citric-acid-producing strain [15], whereas strain N400, the parent strain of laboratory strain N402 used in this study, was originally characterized as an efficient gluconic acid producer [41]. Nevertheless, an oxaloacetate acetylhydrolase mutant of the N402 strain can produce up to $90 \mathrm{~g}$ citric acid from $140 \mathrm{~g}$ sucrose in 10 days [6], and a previously reported genome comparison revealed that its genome and that of strain ATCC 1015 are practically identical [18]. 
Recently, the genome of the extensively mutagenized industrial citric acid hyperproducer H915-1 became available [42]. This strain, which can achieve a citrate titer of $157 \mathrm{~g} / \mathrm{L}$ and a yield of $0.98 \mathrm{~g} / \mathrm{g}$ total sugar, contains several missense mutations in different proteins involved in citrate synthesis [42] that make it a hyperproducer. Nonetheless, apart from the reported missense mutations, and several genome rearrangements and deletions in H915-1, the genomes of $A$. niger N402 and H915-1 show an overall identity at nucleotide level of more than $98 \%$ (see Supplementary Figure S2 online). Based on RNAseq data, comparing the growth and the citrate accumulation phase of the fermentation, Yin et al. [42], reported a list of transporter genes up-regulated during the citrate production phase. This shortlist was proposed to contain candidate citrate transporters, but did not include the cit $T$ gene first discovered by Odoni et al. [19,20].

A single copy of the cit $T$ gene is present in both strains. For the cit $T$ gene we did not observe any nucleotide changes between strains H915-1 and N402, and when the $1000 \mathrm{bp}$ upstream and downstream regions were included in the analysis only a single nucleotide change was observed located downstream of the gene. Since there was no notable change in transcriptional activity of the cit $T$ gene between the growth and production phase in strain H915-1, to study the role of the transporter in the present study three contrasting conditions were compared: (i) citrate producing conditions, (ii) the effect of blocking active export under citrate producing conditions through deletion of the citT gene, (iii) and growth on citrate as carbon source.

\subsection{Transcriptional Regulation of the Citrate Exporter Gene}

A. niger N402 was grown in triplicate using controlled fermentation conditions, maintaining the $\mathrm{pH}$ at 2.5. This $\mathrm{pH}$ was chosen because it is low enough to enable monitoring the secretion of both citric and oxalic acid and to suppress extracellular gluconic acid formation, and high enough to suppress oxalate decarboxylase activity [43]. To observe a significant production of citric acid, fresh mycelium pregrown in CM-SLZ was transferred to SLZ medium with an initial glucose concentration of $120 \mathrm{~g} / \mathrm{L}$. Using these fermentation conditions, biomass increased from $1 \mathrm{~g} / \mathrm{L}$ cell dry weight (CDW) to approximately $15 \mathrm{~g} / \mathrm{L}$ CDW (see Supplementary Table S2 online). Citric acid was secreted and, under the specific conditions applied, a maximal citrate concentration of $28.52 \pm 4.78 \mathrm{~g} / \mathrm{L}$ was obtained after $120 \mathrm{~h}$ of fermentation (Figure 1A). After this timepoint, glucose was depleted from the medium and the cultures started to consume the previously produced citrate. Besides citric acid, oxalic acid was detected in the culture medium, and a final concentration of $15 \mathrm{~g} / \mathrm{L}$ was obtained after $216 \mathrm{~h}$ of fermentation, indicating that oxalic acid production continued after depletion of glucose.

When fresh mycelium pregrown in CM-SLZ was transferred to SLZ medium with citrate as sole carbon source, strain N402 was able to assimilate the citrate, albeit with a much lower efficiency and the initial $9 \mathrm{~g} / \mathrm{L}$ of citrate in the medium was depleted within $72 \mathrm{~h}$ (Figure 1B) while the biomass increased from $1.0 \mathrm{~g} / \mathrm{L}$ to $1.4 \mathrm{~g} / \mathrm{L}$ in $72 \mathrm{~h}$ (see Supplementary Table S1 online). Upon growth on citrate as a sole carbon source a significant amount of oxalic acid was produced, amounting up to $5 \mathrm{~g} / \mathrm{L}$ in $48 \mathrm{~h}$ (Figure 1B). 
A

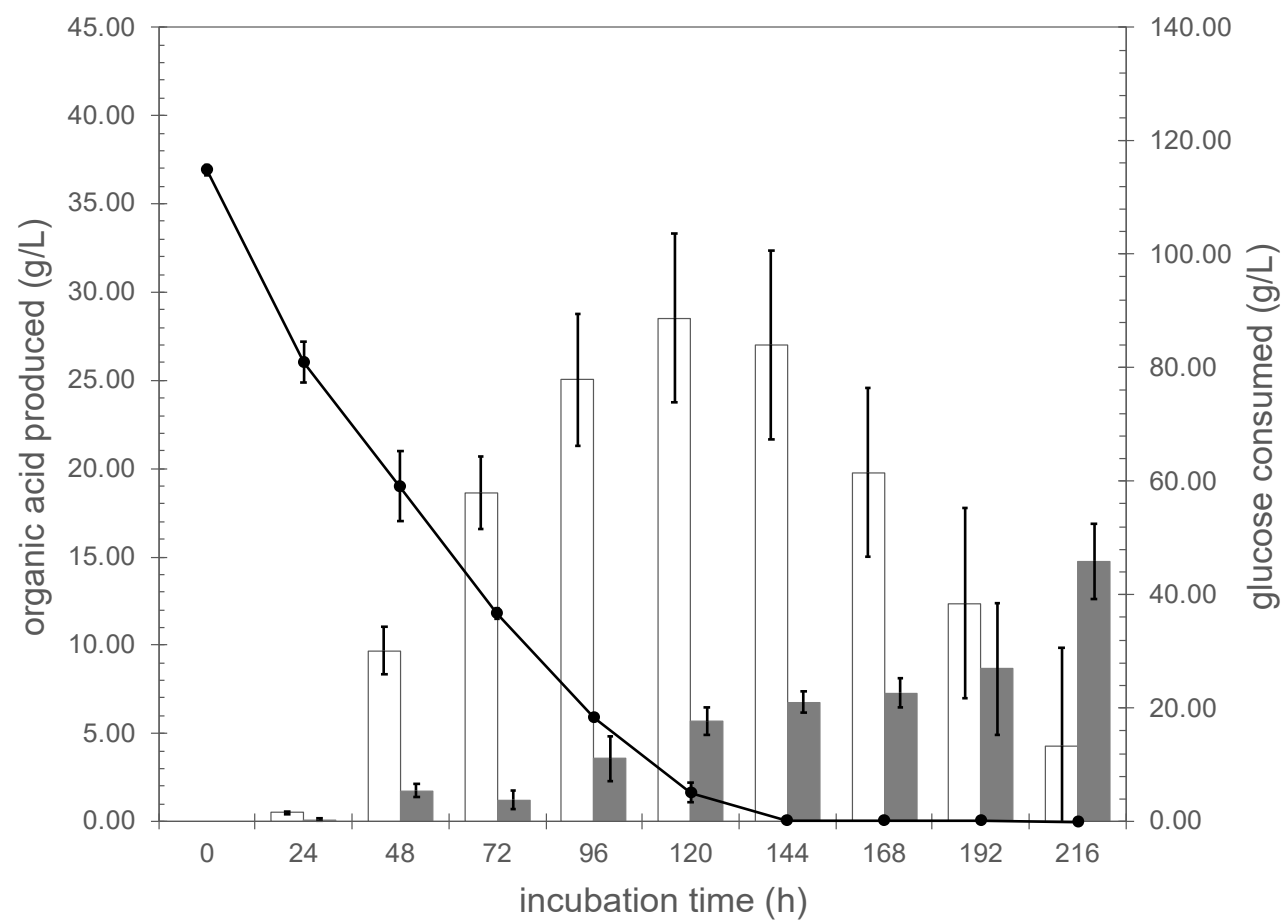

B

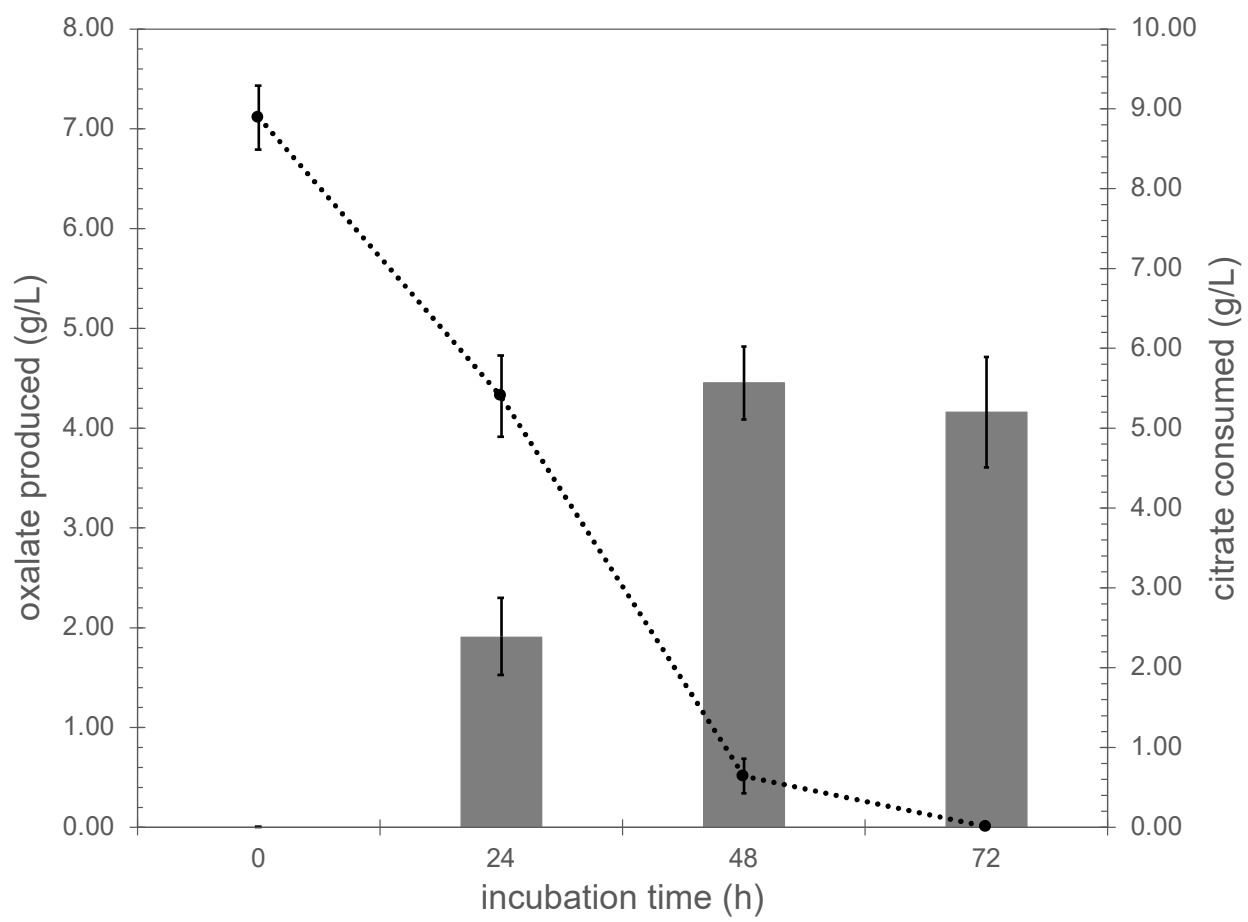

Figure 1. Organic acid profiles of $A$. niger N402 grown in glucose and citrate Panel (A), glucose; white bar, amount of citrate produced, gray bar, amount of oxalate produced, dotted line glucose consumed. Panel (B), citrate; gray bar, amount of oxalate produced, dotted line is citrate consumed. 
To study the transcriptional response of $A$. niger, we compared the transcriptional landscapes (RNAseq) of the N402 strain grown in glucose and citrate at the 48-h timepoint, which was the early phase of citric acid secretion without consumption. RNA expression data were obtained in triplicate and statistically analyzed using the citric-acid-producing condition as reference. Using a threshold $\log _{2}$ (fold change) $\left(\log _{2}(\mathrm{FC})\right)$ value of $\geq 0.50$ or $\leq-0.50$ and $p_{a d j}$ value below $0.05,2257$ of the 11,187 genes were significantly up-regulated while 2217 genes were down-regulated (Figure 2 and Supplementary Data S1 in sheet N402_citrate_vs_glucose online).

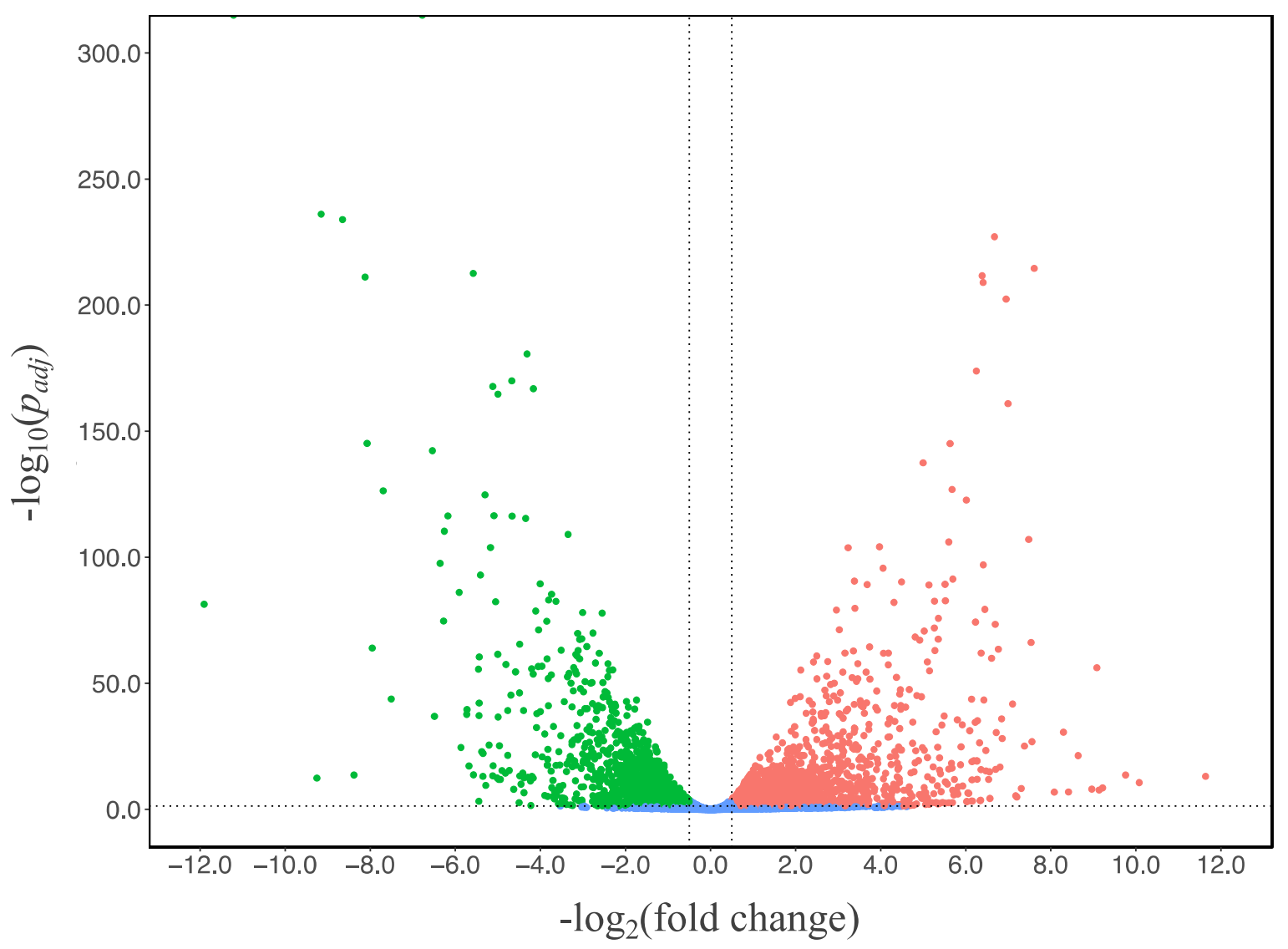

Figure 2. Volcano plot of gene transcript levels of A. niger N402 grown in citrate medium using the data of glucose medium as reference. The regions between the dotted lines indicate the non-significant data.

The CitT exporter protein belongs to Major Facilitator Superfamily (MFS) $[19,20]$. From the 336 putative MFS encoding genes contained in the genome of A. niger N402, 78 and 87 of them were significantly up- and down-regulated in citrate condition compared to glucose (as reference), respectively (Supplementary Data S1 in sheet N402_MFS online). By investigating the list of MFS genes down-regulated upon growth on citrate, a strong downregulation of the citT gene (ATCC64974_65440, corresponding protein id SPB48923.1) was observed with $\log _{2}(\mathrm{FC})$ at -6.777 (Table 1 ). The hundred-fold down-regulation suggested that the citrate exporter protein played no role in citrate uptake and prompted us to further study the consequences of blocking active export under otherwise citric-acidproducing conditions. 
Table 1. Transcript levels of genes in Major Facilitator Superfamily of A. niger N402 grown in citrate medium using glucose medium as the reference (the full list is in Supplementary Data S1 in sheet N402_MFS online).

\begin{tabular}{cccc}
\hline Gene Locus Tag. & Protein ID & $\log _{\mathbf{2}}$ (Fold Change) & TMHs \\
\hline ATCC64974_65440 & SPB48923.1 & -6.7765 & 12 \\
ATCC64974_85340 & SPB50921.1 & -5.5734 & 12 \\
ATCC64974_44020 & SPB46772.1 & -5.0525 & 10 \\
ATCC64974_28550 & SPB45214.1 & -4.9393 & 12 \\
ATCC64974_43890 & SPB46759.1 & -4.8217 & 8 \\
ATCC64974_4840 & SPB42837.1 & -4.7665 & 12 \\
ATCC64974_25910 & SPB44949.1 & -4.4900 & 12 \\
ATCC64974_29710 & SPB45330.1 & -4.1990 & 11 \\
ATCC64974_26160 & SPB44974.1 & -3.8357 & 12 \\
ATCC64974_85360 & SPB50923.1 & -3.8232 & 11 \\
ATCC64974_950 & SPB42446.1 & -3.7484 & 14 \\
ATCC64974_26910 & SPB45050.1 & -3.5111 & 12 \\
ATCC64974_93260 & SPB51716.1 & -3.2956 & 12 \\
ATCC64974_72710 & SPB49652.1 & -3.2174 & 9 \\
ATCC64974_21780 & SPB44533.1 & -3.1779 & 10 \\
ATCC64974_105810 & SPB52979.1 & -3.1237 & 13 \\
ATCC64974_72040 & SPB49585.1 & -3.0387 & \\
ATCC64974_10650 & SPB43419.1 & -3.0383 & \\
\hline
\end{tabular}

\subsection{In Vivo Validation of the A. niger Gene Encoding the Citrate Exporter}

To ascertain the functional role of the cit $T$ gene as the powerfully active export of citrate in its native host, the knock-out of the endogenous $A$. niger cit $T$ gene was performed by replacing the gene with the $A$. oryzae $p y r G$ gene as a selection marker. Three independent knock-out strains were selected for further study.

First, growth of the $\Delta c i t T$ strains were monitored on minimal medium (MM) plates supplemented with glucose as carbon source (see Supplementary Figure S3 online). In comparison to the control strain N402, there was no obvious phenotype change. Moreover, the $\Delta c i t T$ strains were able to grow normally on plates containing citrate as sole carbon source, indicating that the deletion of cit $T$ does not have an impact on citrate import.

The A. niger $\Delta c i t T$ strains were then tested for their ability to secrete citrate in shake flask cultures. Glucose consumption, organic acid concentrations and $\mathrm{pH}$ were followed in time (Figure 3). All strains acidified the medium. When the N402 control strain was used, the $\mathrm{pH}$ dropped from 3.63 to 1.72 in $48 \mathrm{~h}$, and then increased slightly to 1.83 after $96 \mathrm{~h}$ of growth (Figure $3 \mathrm{~A}$ ). When the $\Delta c i t T$ strains were used instead, the $\mathrm{pH}$ dropped to 1.70 after $48 \mathrm{~h}$ of growth and then the $\mathrm{pH}$ remained constant for the next $48 \mathrm{~h}$ (Figure 3B-D). Besides the formation of biomass, the $\Delta c i t T$ strains secreted only oxalic acid, while the control strain (N402) also secreted citrate. Under these conditions, the highest amount of citrate detected was $1.204 \pm 0.053 \mathrm{~g} / \mathrm{L}$, at the $48 \mathrm{~h}$ timepoint in the N402 strain. After this time point, the glucose was depleted, and the secreted citrate was consumed, which may also explain the slight increase in $\mathrm{pH}$ of the $\mathrm{N} 402$ strain cultures at the later time points.

These results reconfirmed that the CitT protein can facilitate active A. niger citrate export, and that knocking out the citT gene significantly impairs the ability of this fungus to secrete citric acid. To further understand the physiological and molecular consequences of a citT deletion on active citrate transport, we sequenced the genome of one of the knockout strains confirming the integrity of this strain and a correct citT deletion and used the controlled fermentation conditions previously employed to study the consequences of blocking active citrate transport under citrate production promoting conditions by HPLC and RNAseq. 
A

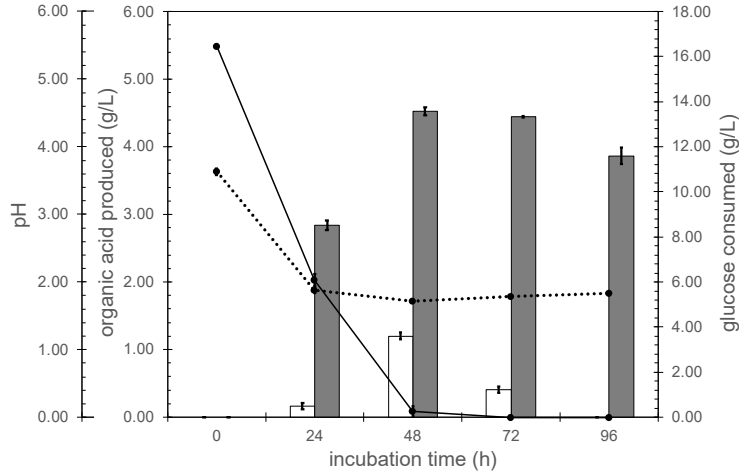

C

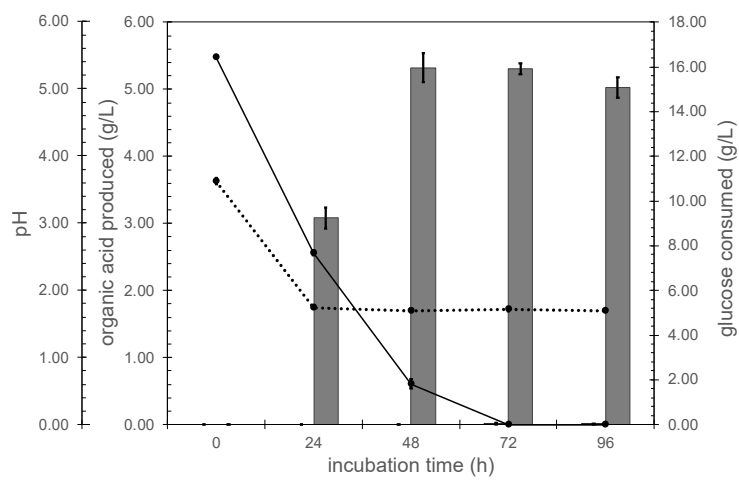

B

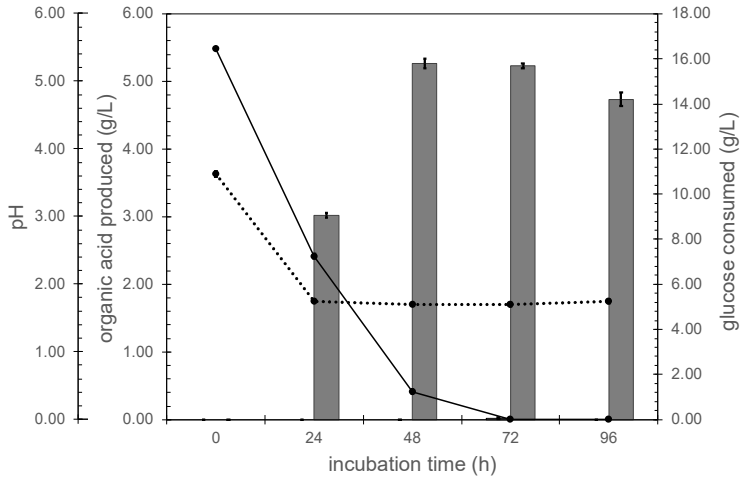

D

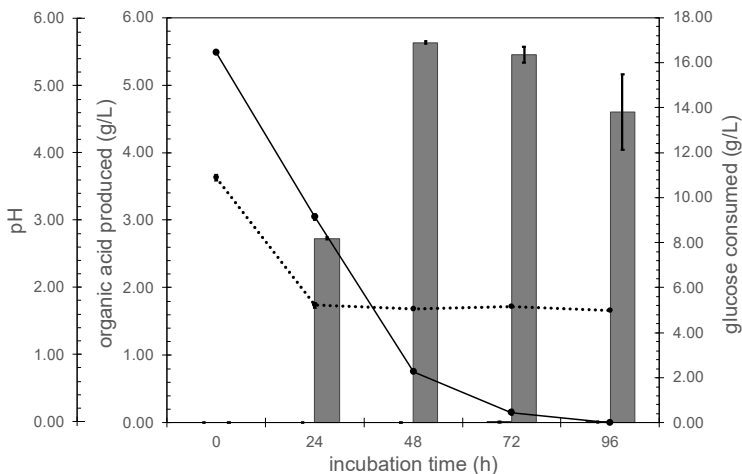

Figure 3. Validation of $A$. niger citT knock-out strains. White bar, the amount of citrate produced; gray bar represents the amount of oxalate produced. Solid line shows glucose concentration and the dotted line corresponds to the culture $\mathrm{pH}$. (A) A. niger N402 control strain, (B) $\Delta$ citT1.1 (C) $\Delta$ citT2.1 and (D) $\Delta$ citT4.1.

\subsection{Organic Acids Production by A. niger Strains N402 and $\Delta$ citT}

Although the specific function of the cit $T$ gene had been described, the gene networks related to this citT gene (and hence, their interplay and role under industrially relevant conditions) are not well-known. Thus, the results herein obtained provide insight into the regulating networks of the citT gene. Using controlled fermentation conditions and glucose as carbon source with the control strain, three major organic acids, citrate, oxalate, and fumarate could be detected as extracellular metabolites while only two, oxalate and fumarate, were detected with the $\Delta c i t T$ strain (Figure 4). The maximal citrate titer produced with the $\Delta c i t T$ strain under the conditions applied was $0.10 \pm 0.04 \mathrm{~g} / \mathrm{L}$ compared to a maximal titer of $28.52 \pm 4.78 \mathrm{~g} / \mathrm{L}$ at $120 \mathrm{~h}$ with the wild-type strain (Figure $4 \mathrm{~A}$ ). Blocking active citrate transport in this way caused two main side effects; (i) the glucose consumption rate of the $\Delta c i t T$ strain was lower than the control strain, and (ii) oxalic acid was the main product of the $\Delta c i t T$ strain (Figure $4 \mathrm{~B}$ ). The $\Delta c i t T$ strain started secreting oxalic acid already within the first $24 \mathrm{~h}$ reaching a titer of $0.132 \pm 0.002 \mathrm{~g} / \mathrm{L}$. At the $72 \mathrm{~h}$ timepoint the reduced glucose uptake of the $\Delta c i t T$ became apparent and the strain also accumulated 5 times more oxalic acid than the control strain $(6.69 \pm 0.08 \mathrm{~g} / \mathrm{L}$ vs. $1.24 \pm 0.54 \mathrm{~g} / \mathrm{L})$. After $216 \mathrm{~h}$, a maximum titer for oxalate of $38.83 \pm 0.69 \mathrm{~g} / \mathrm{L}$ was obtained, matching the solubility of sodium oxalate in water at $30{ }^{\circ} \mathrm{C}$, while the control strain reached a maximum titer of $14.75 \pm 2.11 \mathrm{~g} / \mathrm{L}$. In addition to citrate and oxalate, fumaric acid was detected during the first $24 \mathrm{~h}$ of fermentation, with production levels of $0.72 \pm 0.09 \mathrm{~g} / \mathrm{L}$ for the $\Delta c i t T$ strain and $0.58 \pm 0.09 \mathrm{~g} / \mathrm{L}$ for the control strain. Afterwards, the concentration of fumarate gradually decreased in both cases, not being detected after $144 \mathrm{~h}$ in the culture supernatant of the control strain, and after $216 \mathrm{~h}$ in the case of the $\Delta$ cit $T$ strain culture supernatant (see Supplementary Figure S4 online). 
A

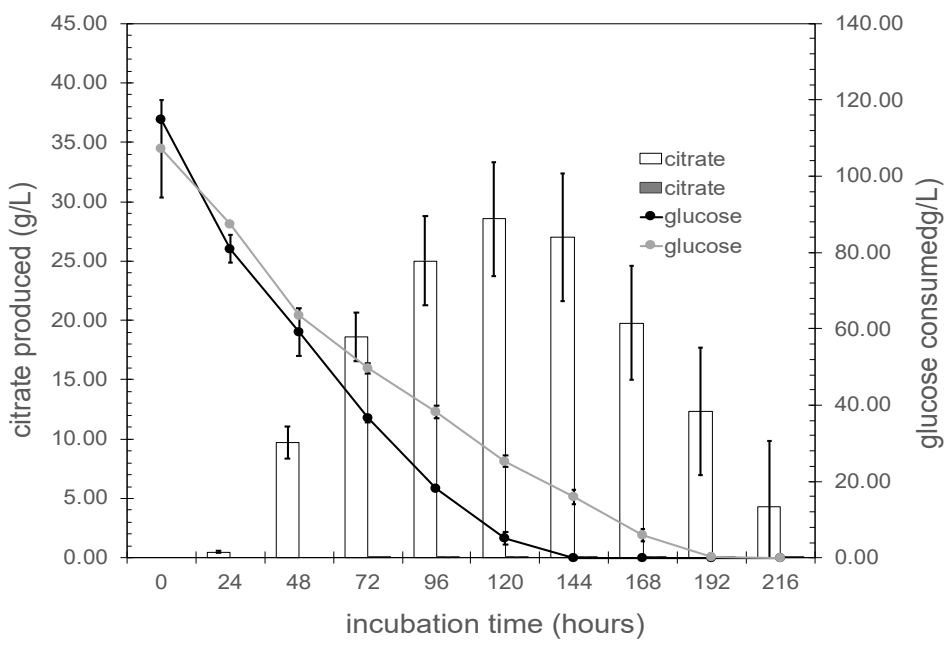

B

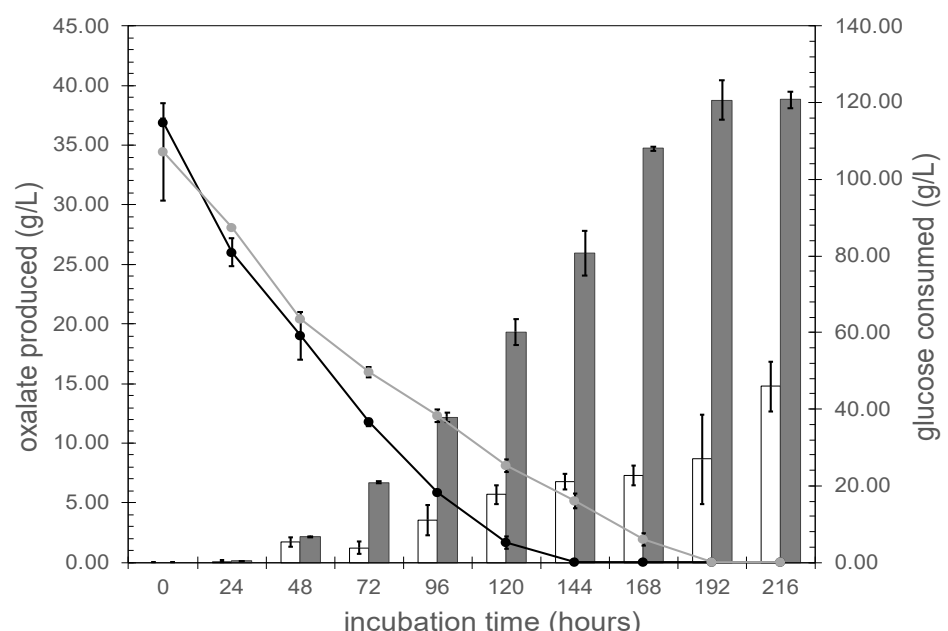

C

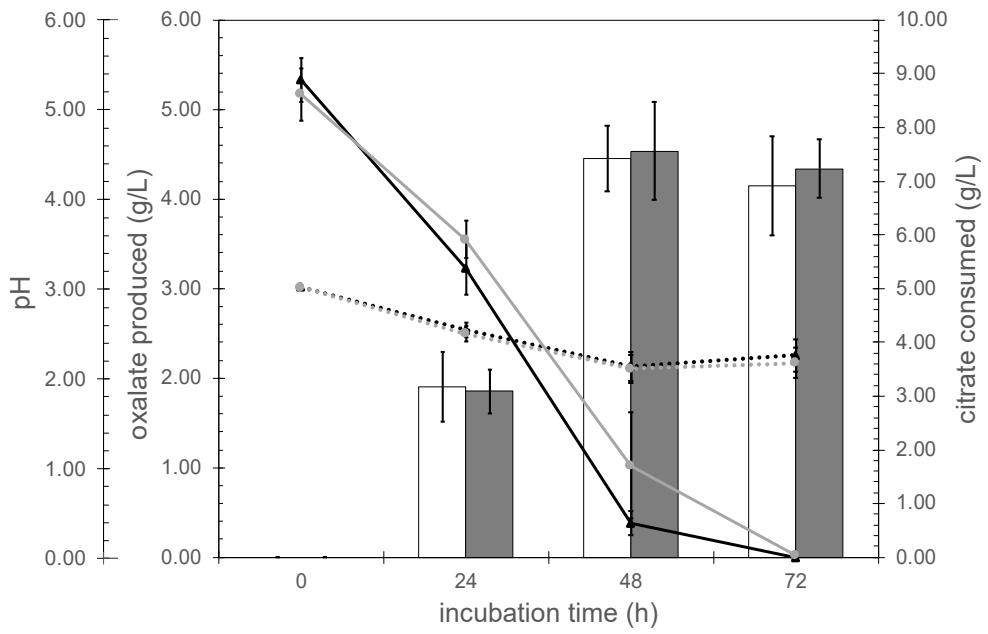

Figure 4. Organic acid production profiles under controlled fermentation conditions. Panel A and $\mathrm{B}$ in glucose at $\mathrm{pH}$ 2.5. Bar graphs represent the concentration of the citrate (A), and oxalate (B) formed. Open bars; N402, gray bars; $\Delta c i t T$. Lines indicate glucose concentration. (C) Growth in citrate medium: bar graph represents oxalate concentrations in citrate medium, open bars; N402, gray bars; $\Delta$ citT. Solid lines indicate citrate consumed, dotted lines indicate the $\mathrm{pH}$.

When the carbon source was changed to citrate, both strains secreted oxalic acid in comparable amounts ( $\Delta$ citT: $4.54 \pm 0.55 \mathrm{~g} / \mathrm{L}$, control strain: $4.45 \pm 0.37 \mathrm{~g} /$ at $48 \mathrm{~h}$ ), although we noted that the citrate consumption rate of the $\Delta c i t T$ strain appeared to be somewhat lower than that of the wild-type strain (Figure 4C). 


\subsection{Transcriptome and Pathway Enrichment Analysis}

To gain further insight in the molecular consequences of blocking active citrate export, the 48-h timepoint was used to explore the transcriptional landscape of the cit $T$ deletion strain by RNAseq, using RNAseq data obtained from the 48-h timepoint of the N402 strain obtained from the same controlled conditions as a reference.

When the transcriptional landscapes of both strains grown in glucose were compared, we observed that the deletion of the cit $T$ gene caused a significant change in the expression of 297 genes, 179 of them being up-regulated and 118 being down-regulated (Figure 5A and Supplementary Data S1 in sheet $\Delta c i t T_{-}$vs_N402_glucose online). On the other hand, when both strains were using citrate as a carbon source, the transcript levels of 141 genes were significantly increased in the $\Delta c i t T$ strain while the expression of 261 genes was significantly decreased (Figure 5B and Supplementary Data S1 in sheet $\Delta c i t T$ _vs_N402_citrate online). Irrespective of the carbon source, as a consequence of the cit $T$ gene deletion, 27 genes were up-regulated (Table 2) and 23 genes were down-regulated (Figure 5C and Table 3).
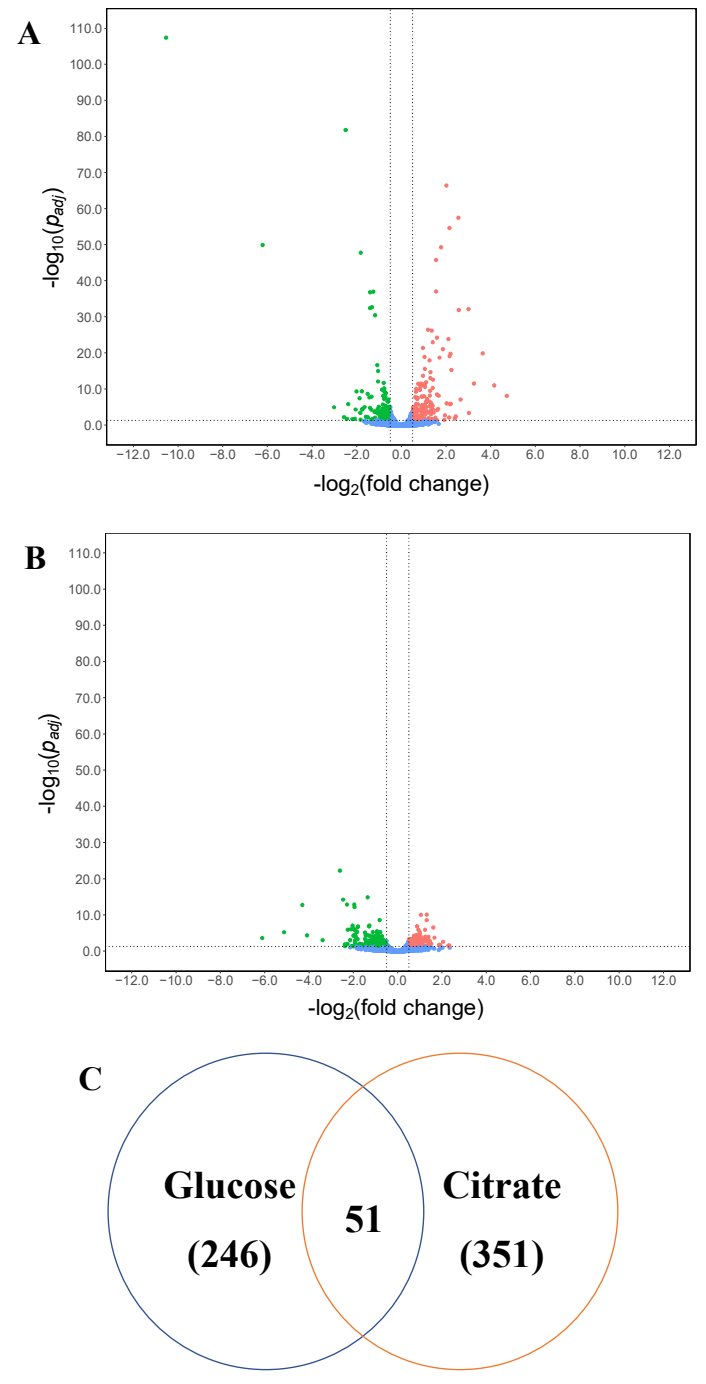

Total 11187 genes

Figure 5. Volcano plot of gene transcript levels in terms of $\log _{2}$ (fold change) of A. niger $\Delta$ cit $T$ grown in glucose (A) and citrate (B) medium. Data of $A$. niger strain N402 was used as the reference. (C) Venn diagram of the $A$. niger $\Delta$ cit $T$ genes expressed in glucose and citrate conditions. The regions between the dotted lines indicate the non-significant data. 
Table 2. Transcript levels of top up-regulated genes affected by the deletion of citT gene (Transcript levels are shown in $\log _{2}$ (fold change) with the $p_{\text {adj }} \leq 0.05$ ).

\begin{tabular}{|c|c|c|c|c|}
\hline & \multirow{2}{*}{ Protein ID } & \multirow{2}{*}{ Description } & \multicolumn{2}{|c|}{$\log _{2}$ (Fold Change) } \\
\hline & & & Glucose & Citrate \\
\hline ATCC64974_103440 & SPB52738.1 & 2OG-Fe(II) oxygenase family oxidoreductase & 4.7227 & 2.2847 \\
\hline ATCC64974_30940 & SPB45454.1 & carboxymuconolactone decarboxylase family protein & 2.3894 & 1.6078 \\
\hline ATCC64974_6060 & SPB42959.1 & HMGL-like family protein & 2.1506 & 1.1072 \\
\hline ATCC64974_91920 & SPB51582.1 & uncharacterized protein & 2.1075 & 0.7707 \\
\hline ATCC64974_63780 & SPB48756.1 & oxaloacetate acetylhydrolase & 2.0182 & 1.9265 \\
\hline ATCC64974_26450 & SPB45003.1 & zinc-binding dehydrogenase family protein & 1.8572 & 1.4575 \\
\hline ATCC64974_15880 & SPB43942.1 & isocitrate lyase & 1.5948 & 0.8524 \\
\hline ATCC64974_67790 & SPB49158.1 & acetyl-CoA hydrolase & 1.5526 & 0.9054 \\
\hline ATCC64974_4720 & SPB42825.1 & O-methyltransferase family protein & 1.4041 & 0.8684 \\
\hline ATCC64974_31190 & SPB45479.1 & malate synthase & 1.3546 & 1.2960 \\
\hline ATCC64974_103400 & SPB52734.1 & uncharacterized protein & 1.3405 & 1.3934 \\
\hline ATCC64974_18700 & SPB44224.1 & alpha/beta hydrolase family protein & 1.2769 & 0.9495 \\
\hline ATCC64974_71600 & SPB49541.1 & uncharacterized protein & 1.2265 & 0.8148 \\
\hline ATCC64974__4600 & SPB42813.1 & AMP-binding enzyme family protein & 1.0504 & 0.6859 \\
\hline ATCC64974_58540 & SPB48229.1 & endo-polygalacturonase B & 0.9209 & 0.7973 \\
\hline ATCC64974_63790 & SPB48757.1 & DUF1275 domain protein & 0.9072 & 1.2557 \\
\hline ATCC64974_47060 & SPB47077.1 & methyltransferase domain family protein & 0.7848 & 1.0456 \\
\hline ATCC64974_102280 & SPB52622.1 & glycosyl hydrolase family 61 family protein & 0.7174 & 0.8594 \\
\hline ATCC64974_82680 & SPB50654.1 & WSC domain family protein & 0.6728 & 0.8253 \\
\hline ATCC64974_4610 & SPB42814.1 & fungal $\mathrm{Zn}(2)-\mathrm{Cys}(6)$ binuclear cluster domain family protein & 0.6693 & 1.3609 \\
\hline ATCC64974_34830 & SPB45846.1 & TAP-like protein family protein & 0.6533 & 0.7306 \\
\hline ATCC64974_104990 & SPB52896.1 & peptidase inhibitor I78 family protein & 0.6393 & 0.5458 \\
\hline ATCC64974_64070 & SPB48785.1 & aldehyde dehydrogenase family protein & 0.6174 & 0.7522 \\
\hline ATCC64974_63760 & SPB48754.1 & purine nucleoside permease & 0.5466 & 0.9801 \\
\hline ATCC64974_34150 & SPB45775.1 & short chain dehydrogenase family protein & 0.5283 & 0.6748 \\
\hline ATCC64974_52850 & SPB47657.1 & mitochondrial NADP- and NAD-isocitrate dehydrogenases & 0.5169 & 0.6755 \\
\hline ATCC64974 34010 & SPB45761.1 & uncharacterized protein & 0.5107 & 0.7421 \\
\hline
\end{tabular}

Table 3. Transcript levels of top down-regulated genes affected by the deletion of cit $T$ gene (Transcript levels are shown in $\log _{2}$ (fold change) with the $p_{a d j} \leq 0.05$ ).

\begin{tabular}{|c|c|c|c|c|}
\hline \multirow{2}{*}{ Gene Locus Tag } & \multirow{2}{*}{ Protein ID } & \multirow{2}{*}{ Description } & \multicolumn{2}{|c|}{$\log _{2}$ (Fold Change) } \\
\hline & & & Glucose & Citrate \\
\hline ATCC64974_89450 & SPB51334.1 & uncharacterized protein & -6.2145 & -4.0918 \\
\hline ATCC64974_9̄92610 & SPB51651.1 & uncharacterized protein & -3.0166 & -1.3542 \\
\hline ATCC64974_1740 & SPB42525.1 & alcohol dehydrogenase & -2.4351 & -1.2566 \\
\hline ATCC64974_12500 & SPB43604.1 & laccase & -2.3820 & -0.7627 \\
\hline ATCC64974_9̋3830 & SPB51773.1 & uncharacterized protein & -2.1959 & -2.0151 \\
\hline ATCC64974_895550 & SPB51344.1 & acid-stable alpha-amylase & -1.8176 & -0.7229 \\
\hline ATCC64974_8_8150 & SPB51204.1 & fungal $\mathrm{Zn}(2)-\mathrm{Cys}(6)$ binuclear cluster domain family protein & -1.7703 & -2.6046 \\
\hline ATCC64974__1920 & SPB42543.1 & uncharacterized protein & -1.7534 & -0.7516 \\
\hline ATCC64974_96990 & SPB52093.1 & high-affinity xylose transporter (XltA) & -1.6515 & -1.4477 \\
\hline ATCC64974_87010 & SPB51090.1 & uncharacterized protein & -1.5061 & -0.7842 \\
\hline ATCC64974_23000 & SPB44655.1 & proteinase aspergillopepsin II & -1.3996 & -1.0743 \\
\hline ATCC64974_81710 & SPB50557.1 & extracellular alpha-glucosidase aglU & -1.3178 & -0.9158 \\
\hline ATCC64974_48920 & SPB47263.1 & carboxypeptidase & -1.0439 & -1.0691 \\
\hline ATCC64974_8̄8220 & SPB51211.1 & mago binding family protein & -0.8482 & -0.5610 \\
\hline ATCC64974_26630 & SPB45021.1 & uncharacterized protein & -0.8254 & -1.2211 \\
\hline ATCC64974_103090 & SPB52703.1 & glycine zipper 2TM domain family protein & -0.7409 & -0.9068 \\
\hline ATCC64974_88240 & SPB51213.1 & ubiquitin-protein ligase E3 component & -0.7202 & -0.5844 \\
\hline ATCC64974_14700 & SPB43824.1 & alpha-glucosidase & -0.7012 & -0.7846 \\
\hline ATCC64974_88190 & SPB51208.1 & cytochrome $\mathrm{P} 450$ alkane hydroxylase & -0.6886 & -0.9308 \\
\hline ATCC64974_88170 & SPB51206.1 & adenylate cyclase AcyA & -0.6885 & -0.6351 \\
\hline ATCC64974_21300 & SPB44485.1 & MFS transporter & -0.6525 & -0.6241 \\
\hline ATCC64974_88210 & SPB51210.1 & protoporphyrinogen oxidase & -0.6309 & -0.5470 \\
\hline
\end{tabular}

An overview of the main differentially expressed metabolic and transporter genes is provided (Figure 6). Since active citrate secretion is blocked in the glucose condition, it appeared that to eliminate intracellular citrate accumulation, two main strategies are used by the $\Delta$ cit $T$ strain: (i) reduction of the glucose uptake rate and (ii) production of oxalic acid. 
At the molecular level, a reduction of glucose uptake was achieved by down-regulation of the transcript levels of the genes encoding the high-affinity glucose transporters $m s t G$ (ATCC64974_41830) and mstH (ATCC64974_29780) [16]. Because the tricarboxylic acid (TCA) cycle cannot act as a carbon sink, the carbon flux towards pyruvate decreased by downregulation of the transcript level of the glucokinase encoding gene, an enzyme that phosphorylates glucose to glucose-6-phosphate and up-regulation of gene ATCC64974_80570 encoding fructose 1,6-biphosphatase normally involved in gluconeogenesis.

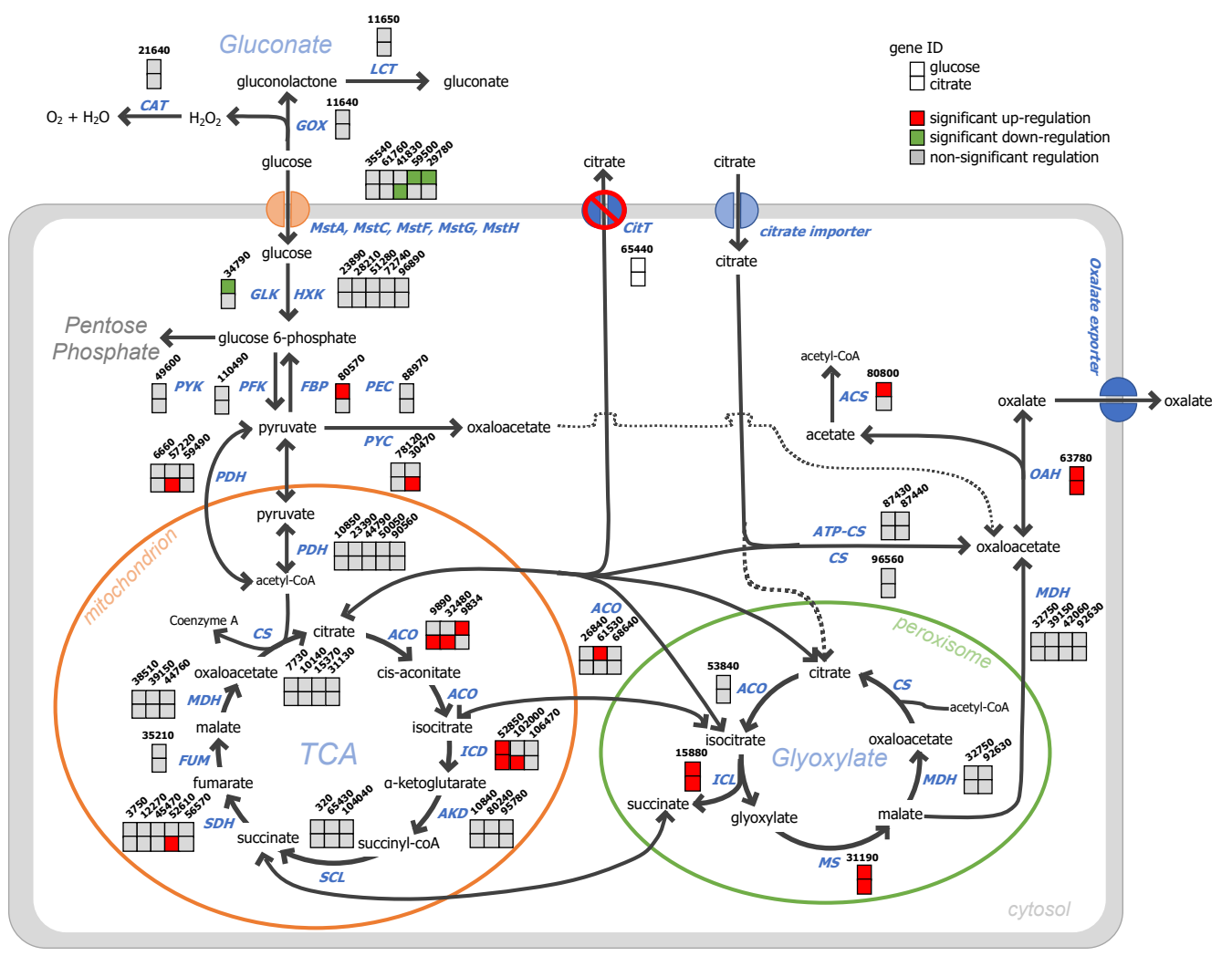

Figure 6. Expression of genes relating in organic acid pathways of $A$. niger $\Delta$ cit $T$ grown in glucose (upper square) and citrate (lower square) medium. Data of $A$. niger strain N402 was used as reference. The solid arrows indicate the main routes of the pathway and the dotted arrows was alternative routes.

To further reduce citrate accumulation, several genes facilitating oxalate production were significantly up-regulated in the cit $T$ deletant strain. In $A$. niger, oxalate is derived from oxaloacetate acetylhydrolase (OAH) [44], and the expression of the OAH encoding gene increased approximately four-fold. Alternatively, citrate can be converted to isocitrate by aconitase. In the $\Delta c i t T$ strain, the transcript levels of the genes encoding a mitochondrial aconitase (ATCC64974_98340) and a cytosolic aconitase (ATCC64974_61530) were significantly increased. Additionally, the genes encoding enzymes of the glyoxylate cycle, isocitrate lyase and malate synthase were strongly up-regulated (Figure 6 and Supplementary Data S1 in sheet organic acid pathways online).

Upon deletion of the cit T gene the expression of 12 and 25 genes encoding proteins of the Major Facilitator Superfamily (MFS; PF07690) significantly changed under glucose and citrate conditions, respectively. In response to a knock-out of the citrate exporter, transcript levels of most of these genes showed a down-regulation (9 genes in glucose and 21 genes in citrate).

Overall, pathway enrichment analysis of the $\Delta c i t T$ strain indicated that nine pathways were enriched in the glucose condition, whereas 25 pathways were shown to be enriched in the citrate condition (Figure 7 and Supplementary Data S1 in sheet pathway enrichment analysis online). Due to the deletion of the citT gene, three pathways showed enrichment irrespective of the carbon source. These three pathways were involved in (1) biosynthesis 
of unsaturated fatty acids, (2) methane metabolism and (3) phenylpropanoid biosynthesis. Although citrate cycle (TCA) was not significantly enriched in both carbon sources, significant enrichment of two pathways related to organic acids production, including glycolysis/gluconeogenesis and glyoxylate and dicarboxylate metabolism, was observed in citrate medium.

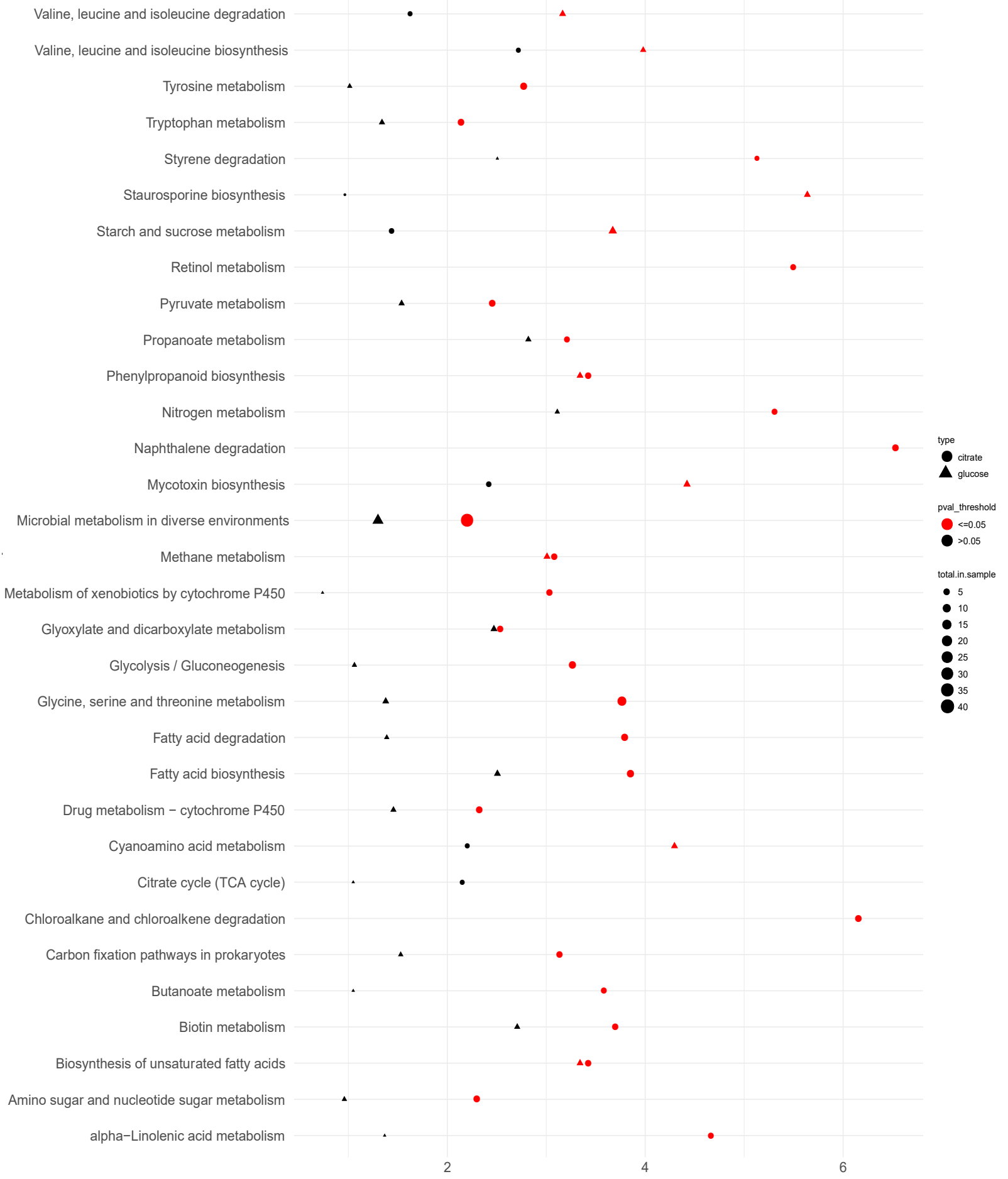

Figure 7. Scatter plot of pathway enrichment analysis of $A$. niger $\Delta$ cit T grown in glucose $(\mathbf{\Delta})$ and citrate $(\bullet)$ medium. The $p$-value at $\leq 0.05$ is represented in red and $>0.05$ in black. Symbol size is related to the number of differentially expressed genes. Data of $A$. niger strain N402 was used as reference. 


\subsection{Distribution of the Citrate Exporter Gene among Aspergillus Species}

Aspergillus section Nigri are prolific producers of in particular citric acids which suggests that a specialized exporter function has evolved for this purpose. The phylogenetic distribution of the citT gene among the various Aspergillus species was investigated by linking Blast similarity scores using the CitT protein as query with the reported ability to secrete citrate obtained from the literature (Figure 8). The analysis showed a clear separation into two groups. Although the query coverage for both groups was shown to be more than $90 \%$, the percentage of sequence identity between both groups differed vastly. The sequence identity between the CitT protein and homologous proteins from other known citrate producing Aspergillus species was more than $71 \%$, while the sequence identity between the $A$. niger citrate transporter and the best hit from non-producers was $42 \%$ or less. Using a bidirectional blast approach, proteins of the second group showed a better hit with two other A. niger N402 transporter proteins (Figure 8). Oxaloacetate hydrolase $(\mathrm{OAH})$ is a member isocitrate lyase/PEP mutase enzyme superfamily of which multiple copies are present in Aspergillus species [45]. Taking advantage of the fact that a conserved active site serine is associated with oxaloacetate hydrolase (OAH) activity [46], the different species were investigated for the presence of the OAH encoding gene. All citrate secreting species also have an $\mathrm{OAH}$ encoding gene although the distribution among the citrate non-producers varies.

CitT

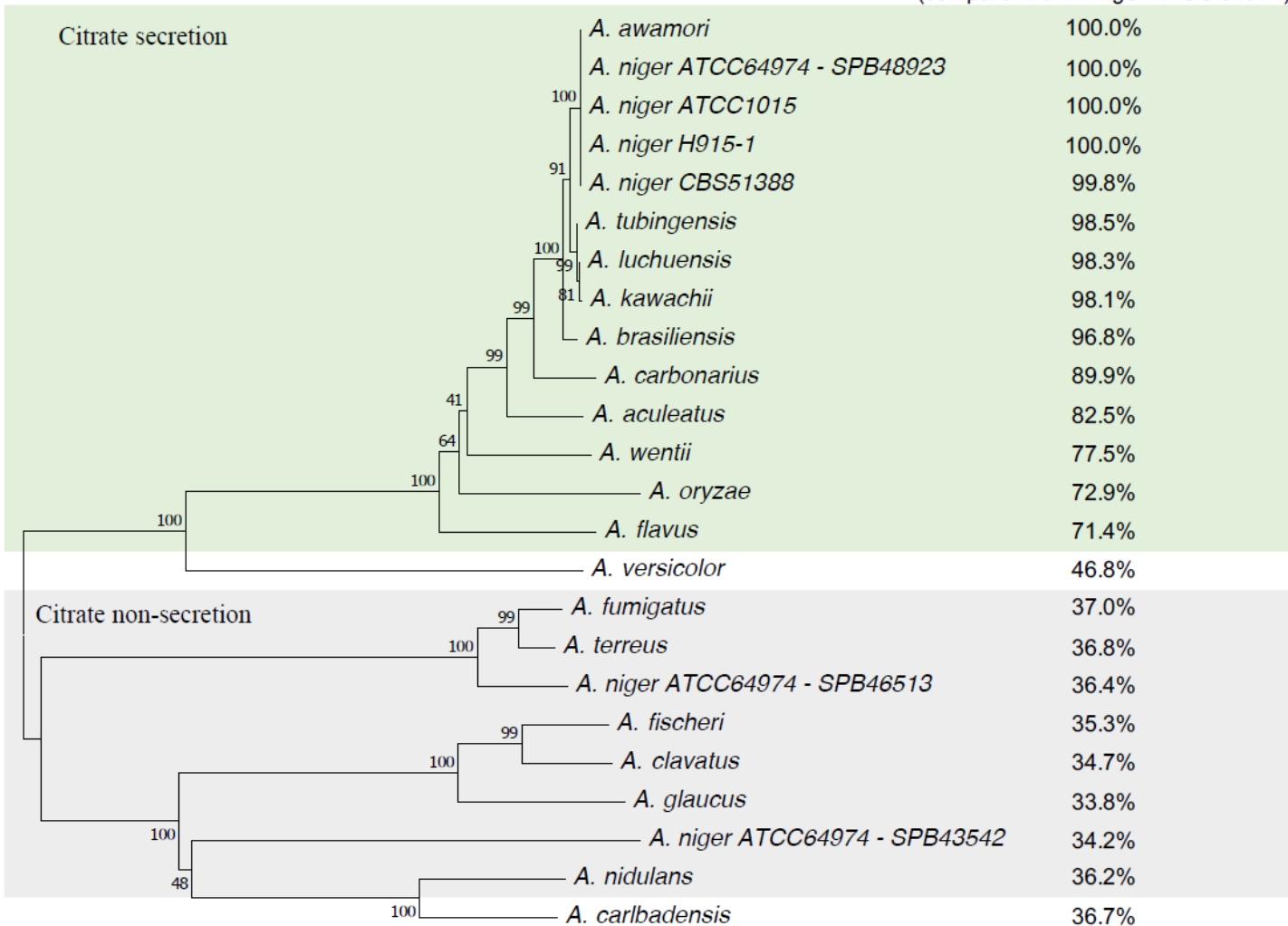

Figure 8. Phylogenetic relationships of the top-scoring candidate citrate exporters (CitT) of Aspergillus species. Known citrate secretors are shaded green, known citrate non-secretion are shaded gray. For A. versicolor and A. carlbadensis no data on citrate production could be found. A. niger SPB46513 and SPB43542 are best-hit paralogous sequences with homologs in non-secretors. Deduced amino acid sequences were aligned using ClustalX, followed by analysis using neighbor-joining in MEGA7. Numbers at nodes indicate bootstrap support following 1000 iterations. The protein sequences are found in Supplementary File S1 online. 


\section{Discussion}

Next to establishing the most optimal fermentation conditions and unravelling the biochemistry of citric acid formation, at least three major regulatory steps of membrane transport, namely (1) hexose uptake, (2) citrate export from the mitochondrion to cytosol and (3) citrate export through the plasma membrane have been considered to be means to further improve citrate production in A. niger [13,47]. Limited research on citrate plasma membrane transport systems has been done [20-22,31]. Due to the significant difference in $\mathrm{pH}$ between the cytosol and the extracellular medium, citrate is present in a dissociated form (citrate ${ }^{2-}$ ) in the cytosol, at a pH between 6.0 and 7.0, and present in an undissociated form in the extracellular environment with a $\mathrm{pH}$ below 2.0 [8-10]. Both forms of citrate can cross the cell wall and export as well as uptake of citric acid in $A$. niger occurs by separate proton-dependent active symport systems. This transport is considered to be an industrial bottleneck for citrate production [48].

Recently, a gene facilitating citrate secretion (cit $T$, alternative name cexA) of A. niger was discovered and partially characterized [19-21]. The RNAseq analysis we did in this study indicated that citT expression levels can vary at least a hundred-fold (Table 1). Furthermore, a sequence alignment between the single copy citT gene of N402 with the single copy cit $T$ gene from the heavy mutagenized industrial citrate-hyperproducing strain H915-1 indicated an almost hundred percent identity in nucleotide sequence of the gene and upstream and downstream region, which may suggest that nor the expression level of the exporter gene or exporter itself is a limiting factor in citrate production.

\section{1. citT Is Responsible for Active A. niger Citrate Export, but Not for Citrate Uptake}

In this study, the consequences of deleting the $A$. niger citrate exporter gene, effectively blocking active citrate export, were examined by studying the consumption of glucose and citrate as carbon sources, monitoring the secretion of organic acids and by transcriptome pathway enrichment analysis. The cit $T$ knock-out almost completely abolished citrate export under otherwise citrate promoting conditions. (Table 1). However, we cannot exclude that other transporters have supportive roles in the secretion process. For instance, in the citT knock-out strain in both carbon sources, a down-regulation was observed for transporter gene ATCC64974_21300. ATCC64974_21300 is not functionally characterized but a BlastP analysis suggested that it could be a drug $/ \mathrm{H}^{+}$antiporter mediating the efflux of a variety of toxic compounds. Nevertheless, genome sequences of Aspergillus species known to secrete citrate clearly have homologs of the cit $T$ gene in single copy, while the second-best (endogenous) hit, encodes a different protein class with a significantly lower percentage of identity. Moreover, this protein class also present in some well-studied non-producers such as $A$. fumigatus.

The $\operatorname{cit} T(\operatorname{cex} A)$ gene is reported as a gene controlling the intracellular and extracellular accumulation of citric acid in white and yellow koji fungi, A. kawachii and A. oryzae, respectively [49]. One homologous cexA gene was found in $A$. kawachii $(A k c e x A)$, which is a species phylogenetically related to $A$. niger, whereas $A$. oryzae carries two intrinsic cex $A$ homolog (AocexA and AocexB). The results of both species showed in the same direction to A. niger. Disruption of $A k c e x A$ gene from $A$. kawachii genome led to significantly reduced citric acid accumulation, whereas overexpression of $A$ kcexA into $A$. oryzae boosted both extracellular and intracellular citric acid accumulation in $A$. oryzae with a comparable level to A. kawachii. Additionally, the overexpression of either AocexA or AocexB into A. oryzae itself under a control of $a m y B$ promoter extremely enhanced the extracellular and intracellular citric acid accumulation [49]. The overexpression of $A k c e x A$ resulted in the up-regulation of 10 metabolites on the metabolic pathways closely linked to citric acid production including citric acid and isocitric acid (tricarboxylic acid (TCA) cycle); glucose 6-phosphate, and 3-phosphoglyceric acid (glycolysis); trehalose 6-phosphate (trehalose synthesis pathway); 6-phosphogluconic acid, ribose 5-phosphate, ADP-ribose, UDP, and $\mathrm{NADP}^{+}$(pentose phosphate pathway) [49]. 
4.2. Blocking Active Citrate Export under Citrate Producing Conditions Reduces the Uptake of Glucose, Induces the Secretion of Oxalic Acid, and Activates the Glyoxylate Shunt

The transcriptome and pathway enrichment analysis in citrate exporting and importing conditions showed that in the presence of glucose, the high glycolytic flux normally present in citrate producing conditions was counterbalanced by a slower glucose consumption (Figure 4), coinciding at the molecular level with down-regulation of the genes encoding high-affinity glucose transporters, mstG (ATCC64974_41830) and mstH (ATCC64974_29780) (Figure 6 and Supplementary Data S1 in sheet organic acid pathways online). To further compensate for the absence of active citrate, transport oxalate production was significantly increased. Although it was reported that oxalate formation at the lower $\mathrm{pH}$ ranges from 1.5 to 2.5 is limited [9], in the fermentation experiment controlled at $\mathrm{pH} 2.5$, oxalate was detected as the predominant organic acid at the maximum concentration that can be achieved under given conditions (Figure 4B). Transcriptome analysis provided molecular insight in how the surplus of citrate was converted to oxalate (Figure 6). First, citrate is converted by mitochondrial aconitases to cis-aconitate and then to isocitrate, respectively. The glyoxylate shunt is activated by the overexpression of the genes encoding isocitrate lyase and malate synthase. Malate is the main product of this pathways. It is used as a substrate to produce oxaloacetate by cytosolic malate dehydrogenase. Finally, oxaloacetate is hydrolyzed in oxalate and acetate by oxaloacetate acetylhydrolase (ATCC64974_63780). Upon oxalate secretion normally no accumulation of acetate is observed in the medium, which suggests that the acetate formed is quickly re-metabolized preventing secretion $[6,9]$. In the $\Delta c i t T$ strain, up-regulation of acetyl-CoA synthase, an enzyme catalyzing the formation of cytosolic acetyl-CoA from acetate, was observed. (Figure 6 and Supplementary Data S1 in sheet organic acid pathways online). Using citrate as a substrate, normally ATP citrate lyase is responsible for the generation of cytosolic acetylCoA; however, we did not observe up-regulation of the two encoding genes. Pathway enrichment analysis showed that biosynthesis of unsaturated fatty acids (map01040) was significantly increased in the cit T gene deletion strain. As a result, the knock-out might lead to production of fatty acids, especially linolenic acid, which was reported as a major unsaturated fatty acid produced under citrate accumulation conditions [50].

Citrate can be used as sole carbon and energy source by $A$. niger $[48,51]$. As the knock-out strain showed a normal growth on citrate this suggests that the fungus has a separate (active) citrate uptake system, as was first suggested by Netik et al. [48]. For this A. niger may have developed specific transporters facilitating citrate import or it may use carboxylic acid transporters, some of which have been shown to transport citrate [52] In the latter case ATCC64974_67850 and/or ATCC64974_45030, which are homologs of the genes encoding JenA and JenB carboxylic acid transporters in A. nidulans, respectively [53] are candidates, as both show high expression levels in citrate medium compared to glucose medium in both strains (Supplementary Data S1 in sheet All_RNASeq data online).

\section{Conclusions}

In summary, our study suggests that the cit $T$ gene is responsible for active $A$. niger citrate export, but not for citrate uptake. Blocking active citrate export under citrate producing conditions reduces the uptake of glucose, induces the secretion of oxalic acid and activates the glyoxylate shunt. Growth on citrate in addition leads to oxalic acid formation. Thus, by deleting a single gene, it is feasible not only to eliminate the undesired secondary formation of citric acid in the primary production of other organic acids such as oxalic and gluconic acid but also to significantly improve their production yields, even at low $\mathrm{pH}(\mathrm{pH}$ 2.5). These insights are very valuable for the design and steering improved industrial production of organic acids by $A$. niger. 
Supplementary Materials: The following are available online at https:/ / www.mdpi.com/article/10 .3390/jof7060409/s1. Supplementary Data S1: Transcriptomic and Pathway Enrichment Analysis; Supplementary Figure S1: Scheme representing experimental steps for deletion of cit $T$ gene from the A. niger genome; Supplementary Figure S2: Sequence identity and synteny between the proposed genome assemblies of Aspergillus niger strains N402 and H915-1; Supplementary Figure S3: Growth of $A$. niger strain N402 and $\Delta$ citT on MM plates; Supplementary Figure S4: Fumaric acid production by fermentation in glucose medium of $A$. niger strain N402 and $\Delta$ citT; Supplementary Table S1: Cell dry weight of $A$. niger strain N402 and $\Delta c i t T$ grown on various carbon sources by fermentation; Supplementary Table S2: Primers used in this study; Supplementary File S1: Amino acid sequences of candidate citrate exporter (CitT) of Aspergillus species.

Author Contributions: T.L. and P.J.S. conceived and designed the work. T.L., L.B. and T.S. performed the experiments. T.L., B.N., M.S.-D. and P.J.S. analyzed and interpreted the data. T.L. and P.J.S. drafted the manuscript. T.L., J.A.T.-R. and V.A.P.M.d.S. critically revised the manuscript for intellectual content. All authors have read and agreed to the published version of the manuscript.

Funding: Thanaporn Laothanachareon is financially supported by a Royal Thai Government Scholarship and National Science and Technology Development Agency (NSTDA), Thailand.

Institutional Review Board Statement: Not applicable.

Informed Consent Statement: Not applicable.

Data Availability Statement: The raw sequencing data (DNA and RNA) have been submitted to the European Nucleotide Archive (ENA) and can be found under the accession number ERS3465414.

Acknowledgments: We would like to thank Mark Arentshorst for providing us the A. niger MA169.4 strain and Wasin Poncheewin for his contribution in the visualization of the RNAseq results.

Conflicts of Interest: The authors declare that the research was conducted in the absence of any commercial or financial relationships that could be construed as a potential conflict of interest.

\section{References}

1. Fiedler, M.M.; Nitsche, B.; Wanka, F.; Meyer, V. Aspergillus: A cell factory with unlimited prospects. In Applications of Microbial Engineering, 1st ed.; Gupta, V.K.S., Monika Maki, M., Tuohy, M., Mazutti, M.A., Eds.; CRC Press: Boca Raton, FL, USA, 2013; pp. 1-51.

2. Show, P.L.; Oladele, K.O.; Siew, Q.Y.; Aziz Zakry, F.A.; Lan, J.C.-W.; Ling, T.C. Overview of citric acid production from Aspergillus niger. Front. Life Sci. 2015, 8, 271-283. [CrossRef]

3. Cairns, T.C.; Nai, C.; Meyer, V. How a fungus shapes biotechnology: 100 years of Aspergillus niger research. Fungal Biol. Biotechnol. 2018, 5, 13. [CrossRef]

4. Singh Dhillon, G.; Kaur Brar, S.; Verma, M.; Tyagi, R.D. Recent Advances in Citric Acid Bio-production and Recovery. Food Bioprocess Technol. 2011, 4, 505-529. [CrossRef]

5. Sweis, I.E.; Cressey, B.C. Potential role of the common food additive manufactured citric acid in eliciting significant inflammatory reactions contributing to serious disease states: A series of four case reports. Toxicol. Rep. 2018, 5, 808-812. [CrossRef]

6. Ruijter, G.J.G.; Van de Vondervoort, P.J.I.; Visser, J. Oxalic acid production by Aspergillus niger: An oxalate-non-producing mutant produces citric acid at $\mathrm{pH} 5$ and in the presence of manganese. Microbiology 1999, 145, 2569-2576. [CrossRef] [PubMed]

7. Karaffa, L.; Kubicek, C.P. Aspergillus niger citric acid accumulation: Do we understand this well working black box? Appl. Microbiol. Biotechnol. 2003, 61, 189-196. [CrossRef] [PubMed]

8. Magnuson, J.K.; Lasure, L.L. Organic acid production by filamentous fungi. In Advances in Fungal Biotechnology for Industry, Agriculture, and Medicine; Tkacz, J.S., Lange, L., Eds.; Springer US: Boston, MA, USA, 2004; pp. 307-340.

9. Andersen, M.R.; Lehmann, L.; Nielsen, J. Systemic analysis of the response of Aspergillus niger to ambient pH. Genome Biol. 2009, 10, R47. [CrossRef] [PubMed]

10. Kubicek, C.P.; Zehentgruber, O.; El-Kalak, H.; Röhr, M. Regulation of citric acid production by oxygen: Effect of dissolved oxygen tension on adenylate levels and respiration in Aspergillus niger. Eur. J. Appl. Microbiol. Biotechnol. 1980, 9, 101-115. [CrossRef]

11. Hang, Y.D.; Woodams, E.E. Apple pomace: A potential substrate for citric acid production by Aspergillus niger. Biotechnol. Lett. 1984, 6, 763-764. [CrossRef]

12. Kareem, S.O.; Rahman, R.A. Utilization of banana peels for citric acid production by Aspergillus niger. Agric. Biol. J. N. Am. 2011, 4, 384-387. [CrossRef]

13. Papagianni, M. Advances in citric acid fermentation by Aspergillus niger: Biochemical aspects, membrane transport and modeling. Biotechnol. Adv. 2007, 25, 244-263. [CrossRef]

14. Bateman, A.; Coin, L.; Durbin, R.; Finn, R.D.; Hollich, V.; Griffiths-Jones, S.; Khanna, A.; Marshall, M.; Moxon, S.; Sonnhammer, E.L.L.; et al. The Pfam protein families database. Nucleic Acids Res. 2004, 32, D138-D141. [CrossRef] [PubMed] 
15. Andersen, M.R.; Salazar, M.P.; Schaap, P.J.; Van De Vondervoort, P.J.I.; Culley, D.; Thykaer, J.; Frisvad, J.C.; Nielsen, K.F.; Albang, R.; Albermann, K.; et al. Comparative genomics of citric-acid-producing Aspergillus niger ATCC 1015 versus enzyme-producing CBS 513.88. Genome Res. 2011, 21, 885-897. [CrossRef] [PubMed]

16. Sloothaak, J.; Odoni, D.I.; de Graaff, L.H.; Martins dos Santos, V.A.P.; Schaap, P.J.; Tamayo-Ramos, J.A. Aspergillus niger membraneassociated proteome analysis for the identification of glucose transporters. Biotechnol. Biofuels 2015, 8, 150. [CrossRef] [PubMed]

17. Pel, H.J.; De Winde, J.H.; Archer, D.B.; Dyer, P.S.; Hofmann, G.; Schaap, P.J.; Turner, G.; de Vries, R.P.; Albang, R.; Albermann, K.; et al. Genome sequencing and analysis of the versatile cell factory Aspergillus niger CBS 513.88. Nat. Biotechnol. 2007, 25, $221-231$. [CrossRef]

18. Laothanachareon, T.; Tamayo-Ramos, J.A.; Nijsse, B.; Schaap, P.J. Forward Genetics by Genome Sequencing Uncovers the Central Role of the Aspergillus niger goxB Locus in Hydrogen Peroxide Induced Glucose Oxidase Expression. Front. Microbiol. 2018, 9, 2269. [CrossRef]

19. Odoni, D.I. Organic Acid Production in Aspergillus niger and other Filamentous Fungi; Wageningen University \& Research: Wageningen, The Netherlands, 2017.

20. Odoni, D.I.; Vazquez-Vilar, M.; Van Gaal, M.P.; Schonewille, T.; Martins Dos Santos, V.A.; Tamayo-Ramos, J.A.; Suarez-Diez, M.; Schaap, P.J. Aspergillus niger citrate exporter revealed by comparison of two alternative citrate producing conditions. FEMS Microbiol. Lett. 2019, 366, fnz071. [CrossRef] [PubMed]

21. Steiger, M.G.; Rassinger, A.; Mattanovich, D.; Sauer, M. Engineering of the citrate exporter protein enables high citric acid production in Aspergillus niger. Metab. Eng. 2019, 52, 224-231. [CrossRef] [PubMed]

22. Bos, C.J.; Debets, A.J.M.; Swart, K.; Huybers, A.; Kobus, G.; Slakhorst, S.M. Genetic analysis and the construction of master strains for assignment of genes to six linkage groups in Aspergillus niger. Curr. Genet. 1988, 14, 437-443. [CrossRef]

23. Carvalho, N.D.S.P.; Arentshorst, M.; Jin Kwon, M.; Meyer, V.; Ram, A.F.J. Expanding the ku70 toolbox for filamentous fungi: Establishment of complementation vectors and recipient strains for advanced gene analyses. Appl. Microbiol. Biotechnol. 2010, 87, 1463-1473. [CrossRef]

24. Vishniac, W.; Santer, M. The thiobacilli. Bacteriol. Rev. 1957, 21, 195-213. [CrossRef] [PubMed]

25. Arentshorst, M.; Ram, A.F.J.; Meyer, V. Using Non-homologous End-Joining-Deficient strains for functional gene analyses in filamentous fungi. In Plant Fungal Pathogens: Methods and Protocols; Bolton, M.D., Thomma, B.P.H.J., Eds.; Humana Press: Totowa, NJ, USA, 2012; pp. 133-150.

26. Kirimura, K.; Kobayashi, K.; Ueda, Y.; Hattori, T. Phenotypes of gene disruptants in relation to a putative mitochondrial malate-citrate shuttle protein in citric acid-producing Aspergillus niger. Biosci. Biotechnol. Biochem. 2016, 80, 1737-1746. [CrossRef]

27. Usami, S. Production of citric acid by submerged culture. In Mem School Sci. Engg; Waseda University: Tokio, Japan, 1978; Volume 42, pp. 17-26.

28. Odoni, D.I.; Van Gaal, M.P.; Schonewille, T.; Tamayo-Ramos, J.A.; Martins Dos Santos, V.A.P.; Suarez-Diez, M.; Schaap, P.J. Aspergillus niger secretes citrate to increase iron bioavailability. Front. Microbiol. 2017, 8, 1424. [CrossRef] [PubMed]

29. Arentshorst, M.; Niu, J.; Ram, A.F.J. Efficient generation of Aspergillus niger knock out strains by combining NHEJ mutants and a split marker approach. In Genetic Transformation Systems in Fungi, Volume 1; Van Den Berg, M.A., Maruthachalam, K., Eds.; Springer: Berlin/Heidelberg, Germany, 2015; pp. 263-272.

30. Arentshorst, M.; Lagendijk, E.L.; Ram, A.F. A new vector for efficient gene targeting to the pyrG locus in Aspergillus niger. Fungal Biol. Biotechnol. 2015, 2, 2. [CrossRef]

31. Dobin, A.; Davis, C.A.; Schlesinger, F.; Drenkow, J.; Zaleski, C.; Jha, S.; Batut, P.; Chaisson, M.; Gingeras, T.R. STAR: Ultrafast universal RNA-seq aligner. Bioinformatics 2013, 29, 15-21. [CrossRef] [PubMed]

32. Peng, Y.; Leung, H.C.M.; Yiu, S.M.; Chin, F.Y.L. IDBA-UD: A de novo assembler for single-cell and metagenomic sequencing data with highly uneven depth. Bioinformatics 2012, 28, 1420-1428. [CrossRef] [PubMed]

33. Minkin, I.; Patel, A.; Kolmogorov, M.; Vyahhi, N.; Pham, S. Sibelia: A scalable and comprehensive synteny block generation tool for closely related microbial genomes. In Algorithms in Bioinformatics; WABI 2013; Darling, A., Stoye, J., Eds.; Springer: Berlin/Heidelberg, Germany, 2013; Volume 8126, pp. 215-229.

34. Sloothaak, J.; Tamayo-Ramos, J.A.; Odoni, D.I.; Laothanachareon, T.; Derntl, C.; Mach-Aigner, A.R.; Martins Dos Santos, V.A.P.; Schaap, P.J. Identification and functional characterization of novel xylose transporters from the cell factories Aspergillus niger and Trichoderma reesei. Biotechnol. Biofuels 2016, 9, 148. [CrossRef]

35. Quinlan, A.R.; Hall, I.M. BEDTools: A flexible suite of utilities for comparing genomic features. Bioinformatics 2010, 26, 841-842. [CrossRef] [PubMed]

36. Robinson, M.D.; McCarthy, D.J.; Smyth, G.K. edgeR: A Bioconductor package for differential expression analysis of digital gene expression data. Bioinformatics 2009, 26, 139-140. [CrossRef]

37. R Core Team. R: A language and Environment for Statistical Computing; R Foundation for Statistical Computing: Vienna, Austria, 2017.

38. Kanehisa, M.; Goto, S. KEGG: Kyoto Encyclopedia of Genes and Genomes. Nucleic Acids Res. 2000, 28, 27-30. [CrossRef]

39. Kanehisa, M.; Sato, Y.; Kawashima, M.; Furumichi, M.; Tanabe, M. KEGG as a reference resource for gene and protein annotation. Nucleic Acids Res. 2016, 44, D457-D462. [CrossRef]

40. Maere, S.; Heymans, K.; Kuiper, M. BiNGO: A Cytoscape plugin to assess overrepresentation of Gene Ontology categories in Biological Networks. Bioinformatics 2005, 21, 3448-3449. [CrossRef] [PubMed] 
41. Blom, R.H.; Pfeifer, V.F.; Moyer, A.J.; TraufRer, D.H.; Conway, H.F.; Crocker, C.K.; Farison, R.E.; Hannibal, D.V. Sodium gluconate production. Fermentation with Aspergillus niger. Ind. Eng. Chem. 1952, 44, 435-440. [CrossRef]

42. Yin, X.; Shin, H.-D.; Li, J.; Du, G.; Liu, L.; Chen, J. Comparative genomics and transcriptome analysis of Aspergillus niger and metabolic engineering for citrate production. Sci. Rep. 2017, 7, 41040. [CrossRef]

43. Emiliani, E.; Riera, B. Enzymatic oxalate decarboxylation in Aspergillus niger: II. Hydrogen peroxide formation and other characteristics of the oxalate decarboxylase. Biochim. Biophys. Acta (BBA) Enzymol. 1968, 167, 414-421. [CrossRef]

44. Kubicek, C.P.; Schreferl-Kunar, G.; Wöhrer, W.; Röhr, M. Evidence for a cytoplasmic pathway of oxalate biosynthesis in Aspergillus niger. Appl. Environ. Microbiol. 1988, 54, 633-637. [CrossRef] [PubMed]

45. Joosten, H.-J.; Han, Y.; Niu, W.; Vervoort, J.; Dunaway-Mariano, D.; Schaap, P.J. Identification of fungal oxaloacetate hydrolyase within the isocitrate lyase/PEP mutase enzyme superfamily using a sequence marker-based method. Proteins Struct. Funct. Bioinform. 2008, 70, 157-166. [CrossRef]

46. Han, Y.; Joosten, H.-J.; Niu, W.; Zhao, Z.; Mariano, P.S.; McCalman, M.; van Kan, J.; Schaap, P.J.; Dunaway-Mariano, D. Oxaloacetate hydrolase, the C-C bond lyase of oxalate secreting fungi. J. Biol. Chem. 2007, 282, 9581-9590. [CrossRef]

47. Guebel, D.V.; Torres Darias, N.V. Optimization of the citric acid production by Aspergillus niger through a metabolic flux balance model. Electron. J. Biotechnol. 2001, 4. [CrossRef]

48. Netik, A.; Torres, N.V.; Riol, J.-M.; Kubicek, C.P. Uptake and export of citric acid by Aspergillus niger is reciprocally regulated by manganese ions. Biochim. Biophys. Acta (BBA) Biomembr. 1997, 1326, 287-294. [CrossRef]

49. Nakamura, E.; Kadooka, C.; Okutsu, K.; Yoshizaki, Y.; Takamine, K.; Goto, M.; Tamaki, H.; Futagami, T. Citrate exporter enhances both extracellular and intracellular citric acid accumulation in the koji fungi Aspergillus luchuensis mut. kawachii and Aspergillus oryzae. J. Biosci. Bioeng. 2020, 131, 68-76. [CrossRef]

50. Jernejc, K.; Vendramin, M.; Cimerman, A. Lipid composition of Aspergillus niger in citric acid accumulating and nonaccumulating conditions. Enzym. Microb. Technol. 1989, 11, 452-456. [CrossRef]

51. Šimkovič, M.; Kaliňák, M.; Burgstaller, W.; Varečka, L.U. Characterization of an inducible citrate uptake system in Penicillium simplicissimum. FEMS Microbiol. Lett. 2002, 213, 21-26. [CrossRef] [PubMed]

52. Guo, H.; Liu, P.; Madzak, C.; Du, G.; Zhou, J.; Chen, J. Identification and application of keto acids transporters in Yarrowia lipolytica. Sci. Rep. 2015, 5, 8138. [CrossRef] [PubMed]

53. Sá-Pessoa, J.; Amillis, S.; Casal, M.; Diallinas, G. Expression and specificity profile of the major acetate transporter AcpA in Aspergillus nidulans. Fungal Genet. Biol. 2015, 76, 93-103. [CrossRef] [PubMed] 